\title{
Exploring The Innovativeness Of The South Caucasus Economies: Main Trends And Factors
}

https://doi.org/10.21272/sec.5(4).122-148.2021

Ibrahim Niftiyev, ORCID ID: https://orcid.org/0000-0003-3437-9824

$\mathrm{PhD}$ Candidate, University of Szeged, Institute of Finance and International Economic Relations, Hungary

Researcher, Azerbaijan State University of Economics (UNEC), Centre for Studies on European Economy (AIM), Azerbaijan

Nargiz Yagublu, ORCID ID: https://orcid.org/0000-0002-0301-0082

Master of Science in International Management, Goethe University Frankfurt, Germany

Narmin Akbarli, ORCID ID: https://orcid.org/0000-0001-9471-7421

Master of Science in European Studies - EU Regional Policy, University of Wroclaw, Poland

\begin{abstract}
The main purpose of the present research is to establish an exploratory picture of innovativeness in Armenia, Azerbaijan, and Georgia. The main trends and key determinants of innovativeness in the South Caucasus have rarely been investigated in mainstream economic research. However, the South Caucasus is a rapidly developing post-Soviet region, and it is geographically strategic for several key players in the global economy, including China and the European Union (EU). In fact, the role of the South Caucasus in international economic agreements is growing due to increased partnerships between Eastern and Western countries. Thus, the region's current and future innovativeness will determine its integration into global value chains (GVCs). This study employs figure analysis to examine and compare the innovativeness of individual countries and the region as a whole against relevant economic and institutional indicators discussed in the literature. Using scatter plots, a polynomial trendline approach allowed the data to be divided into more meaningful periods of analysis to better understand peaks and dips in national innovativeness in association with selected economic and institutional indicators in the South Caucasus. Overall, the results show that economic growth and economic freedom play an important role in innovativeness in the South Caucasus, while institutional factors present more of a mixed picture. More specifically, the region's overall innovativeness was positively correlated with rule of law and property rights to a certain extent, but this association was not consistent. In addition, Armenia and Georgia experienced higher growth in national innovativeness between 2011 and 2020, while this growth was weaker in Azerbaijan. This paper's results may help the South Caucasus countries conceptualize their innovativeness in terms of the region's overall innovativeness and key economic and institutional variables. Moreover, more sophisticated quantitative techniques and econometric models may be applied in future research.
\end{abstract}

Keywords: Armenian economy, Azerbaijani economy, Georgian economy, determinants of innovativeness, figure analysis, national innovativeness, South Caucasus.

JEL Classification: E02, O30, R11.

Cite as: Niftiyev, I., Yagublu, N., Akbarli, N. (2021). Exploring The Innovativeness Of The South Caucasus Economies: Main Trends And Factors. SocioEconomic Challenges, 5(4), 122-148. https://doi.org/10.21272/sec.5(4).122-148.2021.

Received: 28.10.2021 Accepted: 30.11.2021 Published: 30.12.2021 
SocioEconomic Challenges, Volume 5, Issue 4, 2021

ISSN (print) - 2520-6621, ISSN (online) - 2520-6214

Copyright: (C) 2021 by the authors. Licensee Sumy State University, Ukraine. This article is an open access article distributed under the terms and conditions of the Creative Commons Attribution (CC BY) license (https://creativecommons.org/licenses/by/4.0/).

\section{Introduction}

The intensification of globalization, the advancement of scientific communities, and the improvement of human capital have led to an increase in innovative activities among both developing and developed countries (Strahl and Sobczak, 2017). Schumpeter (1934) pioneered the classification of innovations by identifying new products, production methods, supply sources, markets, and forms of business organization as main types of innovation. In other words, innovation is analogous to novelty. Novelty or innovation emerges due to innovative activities. Similarly, the Organisation for Economic Co-operation and Development (OECD) and Eurostat's (2005) manual define innovation as a newly developed product (either good or services), marketing method or process, or organizational method in business practices, organizations, or external relations. Thus, innovative activities include "all scientific, technological, organizational, financial and commercial steps which actually, or are intended to, lead to the implementation of innovations" (OECD and Eurostat, 2005, p. 47).

The rising importance of innovative activities accelerates the capacity of governments to adopt more innovation-friendly policies to reform national economies, as innovations can help firms, countries, and regions became more competitive and productive (Gunday et al., 2011; Feder, 2018). The quality and efficiency of innovation policies determine the competitiveness of national economies (Kstric et al., 2016). Similarly, innovative activities can help explain differences between rich and poor countries as well as world income distribution. The primary determinants of innovative activities encompass research and development (R\&D) activities, information communication technologies (ICTs), advanced human skills (mainly supported by tertiary or secondary education), and established infrastructures. Thus, developing countries must focus on specific policies to reform their economies and catch up with developed countries by improving technological capabilities (Castellaci, 2011).

Innovation may take place at different levels within a country. For instance, innovation may occur at the firm level but also be scaled up at the national level. Based on the various definitions of innovation, BrodowskaSzewczuk (2019) argued that, in a macroeconomic sense, the momentum for innovativeness depends on the scale of R\&D expenditures and technological progress. Under these circumstances, it can be said that innovativeness changes from country to country and region to region, as it is determined by a number of fundamental factors. For instance, Czyżewska and Mroczek (2014) reported the significant impact of patent applications and business expenditures on $\mathrm{R} \& \mathrm{D}$ and the important role of cooperation among small and medium enterprises (SMEs) in introducing innovations. Moreover, Czyżewska and Mroczek (2014: 54) emphasized the indirect impact of the quality of research systems on innovativeness, especially "scientific co-publications and public R\&D expenditures, and then scientific publications among top $10 \%$ most cited and public-private copublications." In addition, Cezrniak (2017) identified a correlation between the innovativeness of an economy and cultural features of society: innovations are highly likely to occur if individualism, future-orientedness, monochronism, and low power distance are present in a country.

The collapse of the Soviet Union gave rise to 15 newly independent countries that faced shock therapy and a rapid adaptation process to catch up with the leading market economies of the world. The notion of introducing innovativeness into economic production practices was also new and unusual to these transition economies, which faced many hurdles. Various transition economies have not established innovation-led SMEs to foster national competitiveness (Ahmadov, 2020a). In addition, business-oriented innovation is weak among emerging and transitional countries (Ahmadov, 2020b), but they have rapidly caught up with more advanced countries by adopting foreign knowledge and technology (Filippetti and Peyrache, 2011). Therefore, as a collection of postSoviet country and a geographic transit hub between the East and the West, the South Caucasus presents an interesting case study of innovativeness in national economies. In fact, the level and intensity of innovativeness in the region may mirror its development and openness to world markets to boost foreign relations and 
economic advantages. However, few studies to date have evaluated the regional innovativeness of the South Caucasus (Roberts et al., 2013; Korganashvili et al., 2017; Bigos and Wach, 2021). Volatile economic sustainability, increased political instability, and uneven institution- and state-building in the South Caucasus enable an investigation of the relationship between innovativeness and selected socio-economic variables, thereby filling notable gaps in knowledge.

Strahl and Sobczak (2017) argued that studies related to innovativeness address either theoretical and methodological concerns or empirical ones. While theoretical and methodological studies investigate the definitions, types, and measurement of innovations, empirical studies examine levels of assessment for innovativeness. The present paper evaluates the innovativeness of the South Caucasus economies at both the regional and country levels via figure analysis, based on broadly accepted drivers and determinants of innovativeness. The guiding research questions are as follows:

- How has innovativeness and its key drivers changed in the South Caucasus since the recession period (1991-1994)?

- What was the association between economic, institutional, and high technology production and innovativeness (as measured by the Innovations Index) in the South Caucasus between 2011 and 2019 ?

The study is limited to 2011 to 2019 because Innovations Index data provided by Cornell University, Institut Européen d'Administration des Affaires (INSEAD), and the World Intellectual Property Organization (WIPO) was only available for this period. Moreover, the main objectives for the current research are as follows:

- To estimate country- and regional-level growth rates for national innovativeness in the South Caucasus.

- To outline the key events and main nature of the South Caucasus in innovativeness in an aggregate level.

- To determine the direction of the association between national and regional innovativeness in the South Caucasus with regard to the main economic, institutional, and governance indicators.

- To discuss and integrate the results of the results and overall mainstream in the South Caucasus in terms of national and regional innovativeness.

This paper is structured as follows. The literature review section provides an overview of important sources and key determinants of innovation and introduces the main nature of and events related to innovativeness in the South Caucasus economies. The data and methodology section describe the data source and analytical techniques used in the study. The results section reports findings from the figure analysis. The discussion section interprets results related to the innovativeness of the South Caucasus economies. Finally, the last section offers some concluding remarks.

\section{Literature Review}

The main determinants of national innovativeness should be examined and discussed to avoid methodological flaws and shortcomings in studies on national innovation. The literature has captured changing drivers and determinants of innovativeness over time. For instance, Lee (1990) reported that the main variables of national innovation were gross national product (GNP) per capita, literacy rate, the number of scientists and engineers, and the ratio of the manufacturing and services sectors to GNP. Among the key drivers of innovativeness, longterm productivity growth, cross-border technology transfer, and expertise in complex and sophisticated exports also play a significant role (Dieppe, 2021). Moreover, various economic sectors may respond to different factors by becoming more innovative. For example, broadband infrastructure has contributed to innovations in ICTs (Lee et al., 2016); cooperation and propensity to innovate, human capital, adaptation of ICT and media technologies, firm size, and foreign ownership have led to innovations in services and marketing in Australia's tourism sector (Divisekera and Nguyen, 2018); independent inventions and the routine activities of large firms have increased innovative outputs (Baumol, 2005); and university strategies and policies have influenced innovation policies and innovativeness at the regional, national, and supranational levels (Kitagawa, 2010). In addition, Morck and Yeung (2001) have argued that the innovativeness of firms may depend on their ownership structure. In countries where wealthy families control the majority of firms, low levels of innovation are observed because large, wealthy families seek to preserve the status quo and ensure that the government implements protectionist policies. 
Countries with innovative economies are richer and grow more rapidly than their less innovative peers (Morck and Yeung, 2001). However, the absorptive capacity of firms and innovation systems as a whole determines the success of the innovative process, as argued by Borrás and Edquist (2015). In other words, if competencies are mismatched between firms and the national economic system, then innovativeness (or related factors) may fail to build on commercially sound and viable economic outcomes. Both firm-level economies and national economies must be within the range of acceptance to nourish each other to achieve more levels of competitiveness. Tax policies and wages are key drivers of the innovative process. More specifically, low income taxes and high wages can increase the size of the skilled workforce, thus leading to increased innovative activities, especially at the corporate level (Morck and Yeung, 2001).

However, Lee (1990) claimed that national innovativeness is not limited to economic determinants; it also has cultural dimensions. Accordingly, there has been a rising body of literature that discusses the importance of social collaboration and cooperation in understanding innovative activities against the background of noneconomic drivers (OECD, 2011). However, the literature contains conflicting results about the cultural determinants of national innovativeness (Das, 2021). For instance, Mercan and Göktaş (2011) found a positive but non-significant relationship between culture to innovate, which are culture-related factors such as legal, morphological, or other particular elements of economic systems and innovative economic output. In addition, they mentioned that the surveys used to collect data were biased due to the respondents' subjectivity. However, different economic schools largely agree that "tradition-bound, class-conscious societies with hierarchical revealed religions are statistically associated with serious economic problems" (Morck and Yeung, 2001, p. 4). A lack of innovativeness may be an economic problem if a society cannot adapt to changes and ongoing transformations in wealth creation through knowledge-intensive production.

Furthermore, although various studies have analyzed different determinants of innovativeness, innovativeness itself has also evolved into more systematic concepts, such as national innovativeness systems (NIS). The concept of NIS is highly debated and complex due to theoretical and practical peculiarities among scientific circles (Bokachev, 2020). Furthermore, Furman et al. (2002) introduced the term "national innovativeness capacity" and listed public policy as its main determinant. In other words, not only increase in R\&D resources, but the upswing in $\mathrm{R} \& \mathrm{D}$ productivity through the human capital investment, quality of present linkages withincluster circumstances, and innovation incentives should be ensured to catch up with the frontier economies that supply a high amount of high technology products in competitive international markets. Although NIS have become an important point of focus among researchers and several research examples have emerged (Fagerberg and Sapprasert, 2011), this paper does not attempt to apply this concept in the South Caucasus. However, NIS are a useful lens for achieving a more systematic and comprehensive understanding of the context of national innovations or clusters of innovative economies. In fact, Das (2021) mentioned that a more accurate identification of cultural determinants enables a better conceptualization of multi-country innovation projects and government policymaking to spur national innovativeness.

Education and human capital form another axis of innovativeness, although related evidence is debatable and mixed. While certain studies have indicated the importance of both higher education and human capital, others have found one to be more important than the other. Nevertheless, there is a consensus that higher education leads to a more competent labor force, which can boost the research-orientedness of firms and thus lead to more profitable business activities (Leiponen, 2000). For example, Brzozowska and Kabus (2018) discussed the pivotal role of higher education quality, $\mathrm{R} \& \mathrm{D}$, firm-level strategies and policies, public support, and patent applications by comparing Poland and Austria. They found that Austria, whose economy is more grounded in terms of stability of economic growth and development in innovative activities, demonstrated sustainable levels of innovation-led growth and development due to well-organized high education and research centers. Meanwhile, Poland had already begun to catch up with Austria via effective institutional reforms and state stimulation policies. Vocational and skills training comprise another driver of innovativeness that mainly manifests in the pre-R\&D stages (Toner, 2010). In addition, the case of Brazil shows that higher education institutions are central to innovative activities, while the human capital component of innovativeness was less significant and relevant (Schaeffer et al., 2015). However, a region or country's level of innovative output not 
only depends on the number of university graduates and their gainful employment but also a positive relationship between university productivity and commercialization capabilities (Huggins and Johnston, 2009).

In addition, Mercan and Göktaş (2011) tested the relevance of the relationship between universities and the private and concluded that it was significantly connected to innovative output. However, the authors failed to establish a statistically significant link between the industrial clusterings and innovation. Many studies have indicated that the concentration of enterprises in economically specialized regions allows for more innovative activities, as cooperation between enterprises increases (see van der Panne and van Beers, 2006). Meanwhile, country-level cases may reflect a different reality, as demonstrated by Chi and Qian's (2010) finding that education improves spatial innovativeness. Overall, the geographic scope of innovativeness and spatial proximity must be considered to conceptualize differences in innovation policies and activities between large and small territories (Fritsch and Schwirten, 1999).

The specific components of innovativeness play a crucial role in determining the developmental course of the overall Innovations Index. Kstric et al.'s study (2016) identified the availability of scientists and engineers and universitylevel collaboration in R\&D as the most critical factors in innovativeness among EU countries. This may also hold true for the South Caucasus, which is relatively close to Europe in both cultural and geographical terms.

According to Firlej (2019), R\&D expenditures not only significantly and positively impact innovativeness but expenditure structure also plays an important role. Namely, private sector participation noticeably increases innovative outcomes at the regional level, as seen in the case of EU. Stated alternatively, low taxes and high wages can increase the size of the skilled workforce, thus leading to an increase in innovative activities, especially at the corporate level (Morck and Yeung, 2001). Moreover, innovative activities not only depend on institutional or economic mechanisms, but intellectual property rights also influence levels of trade when the relevant institutional mechanisms are absent or dysfunctional (Kuznar and Folfas, 2018). Therefore, a high level of interconnectedness between institutional and economic factors should stimulate policy design when higher institutional activities lead to better innovative and economic output.

Lastly, innovation policies should not blindly aim to increase the size of the educated labor force and improve innovations in the future. Borrás and Edquist (2015) argued that the identification of specific skills that are currently needed and will be important in the future is an urgent priority for overcoming the "skill-biased technological change (SBTC)" hypothesis via effective monitoring mechanisms, which are usually absent. Briefly, SBTC indicates the shift in the production system from unskilled labor toward skilled (more educated, more able, etc.) that also increases the skill premium (ratio of skilled over unskilled labor) in the labor market (Violante, 2016).

\subsection{Armenia}

Like other post-Soviet countries, Armenia's economic structure under central planning and socialism decreased economic agents' motivation to innovate, as market mechanisms and competitiveness were not the state's top priority (Poghosyan, 2017). During and after its transition to a market economy in 1991, Armenia has struggled with an ageing research labor force, low enrollment in science and engineering training programs, and limited R\&D labor resources (Mkrtchyan, 2010). Although its insufficient financial mechanisms, old-fashioned manufacturing sector, and inadequate technology have been serious impediments to innovation, Armenia's welldeveloped laboratories and institutions in the natural sciences, considerable human capital, and large diaspora, which is ready to participate in the country's economy, are positive factors that may fuel innovativeness in the national economy (Poghosyan, 2017). Therefore, on the one hand, considerable state support is needed in Armenia to fill gaps in national innovativeness; on the other hand, Armenia's baseline resources are more conducive to the production of innovative output in the long term compared to Azerbaijan and Georgia.

Armenia's innovative efficiency is higher than other post-Soviet countries such as Kazakhstan and Belarus (Kurmanov et al., 2019). The country's innovativeness is concentrated in the export of ICT services, especially software programming and web design (World Bank Group, 2020). In fact, Armenia's ICT sector is fastgrowing and promises ample new opportunities for emerging GVCs, such as the Chinese Belt and Road 
Initiative and the New Silk Road (Gigauri and Damenia, 2019). The ICT sector in Armenia was progressive even in Soviet times (Gigauri and Damenia, 2019), and there are many positive signs of innovativeness in the Armenian ICT sector. Furthermore, the latter heavily relies on the Armenian diaspora for networking and building social and physical capital (Amirkhanyan, 2017).

Various actions and programs have been initiated by the Armenian government to fuel national innovativeness in different economic sectors, including the Technology Evaluation Program implemented between 2001 and 2013 to boost the country's innovative development of agriculture (Alaverdyan et al., 2015). The Armenian healthcare system has also become more innovative due to the rise of electronic service provision (Chukwuma and Koshkakaryan, 2018). Similarly, social innovation in Armenia has progressed to the extent that it became one of the first countries to host the United Nations Social Innovation Laboratory (Kolba Lab, Radjabov, 2019). Kolba Lab has accelerated social innovation by finding the ideas that compete for social startups in local communities and finding the local government challenges for social innovations (Radjabov, 2019). Although there has been notable progress in Armenia, serious issues and challenges persist with regard to national innovativeness.

For example, R\&D expenditures and scientific autonomy are low in Armenia (Annamária, 2015). There is a lack of partnerships between the industrial and educational sectors, and the state's approach is relatively interventionist (Qin et al., 2017). Moreover, private-sector companies and research institutions and universities in Armenia do not work together to continually update technological capacities and achieve higher innovative outputs (Manucharyan, 2021). There is also a mismatch between market demands and the skills of recent graduates, including in information technologies (IT), which is crucial to many areas of the economy in Armenia (Khechoyan, 2018). Therefore, new regulations and mechanisms must be implemented to support innovativeness of the Armenian economy.

Several solutions have been proposed, some of which have already been implemented. For instance, Avetisyan (2016) recommended leasing as a mechanism for introducing new financial instruments, incentivizing actions to increase innovative output among businesses, and increasing the number of young entrepreneurs, who need active support from the state to participate in ongoing innovative social and commercial innovation processes (Gasparyan, 2020).

\subsection{Azerbaijan}

The crucial role of innovations has been emphasized in development in Azerbaijan since 2012. For example, a government initiative titled "Azerbaijan-2020: Look into the Future" (2012) prioritizes long-term, knowledgebased sustainable economic development that also provides an enabling environment for innovative entrepreneurship and the promotion of science-based products and technologies. The increasing number of startup incubators and accelerators represent preliminary results of the state's approach; however, in addition to seed-stage capital, start-ups require more flexible funding options, such as angel investors (Abdurazzakov and Jafarov, 2016).

Abdurazzakov et al. (2020) found that the Azerbaijani economy becomes innovative when foreign-owned companies operate within the country and when institutions of higher education begin to partner with privatesector companies. However, Azerbaijan's national economy is geographically unbalanced; it is mainly based in the capital city of Baku and lacks rural innovators (Huseynova et al., 2019). Rahimova (2020) stressed the importance of government quality control to achieve stable product innovation, especially in the agricultural sector. However, state support and budget financing must be improved to make the digital economy more innovative.

Different economic sectors have demonstrated different realities when it comes to innovativeness in Azerbaijan. For instance, Mir-Babayev et al. (2017) analyzed the construction industry in Azerbaijan and found that gender and national diversity played a significant role in fueling innovativeness. However, the agricultural sector lacked the innovativeness required to make the transformation to intensive farming (Sadigov, 2017). Meanwhile, the Azerbaijani government's e-government practices showed significant improvements via social 
innovations such as the Azerbaijan Service and Assessment Network (ASAN). Notably, Ng and Tan (2018) described the contributions of ASAN services as technological leapfrogging. The central banking sector also adopted innovative practices by allowing blockchain platforms in national banking and video consultations for clients who wish to open a bank account (Mamedov et al., 2020). However, Alguliyev et al. (2018) mentioned the importance of continuous social innovations in public service delivery to achieve more effective feedback mechanisms among citizens and e-service providers. This also applies to the other types of innovations in Azerbaijan, as the institutional environment is far from the desired level for fostering innovativeness, although the fundamental institutional elements are present (Rahmanov et al., 2018).

Innovativeness is crucial for a particular set of industries in Azerbaijan due to the requirements of the changing public and environmental preservation policies. A recent study by Sultanova and Khankishiyeva (2021) examined the gold mining sector in Azerbaijan and suggested the importance of piloting innovative technologies that are essential for environmental protection. Moreover, the innovativeness of Azerbaijan's military sector proved to be effective during the 44-day war with Armenia in 2020 (Bhattacharya and Fernando, 2021). The mass use of military drones was the distinctive feature of the 44-day war between Azerbaijan and Armenia (Iskandarov and Gawliczek, 2021). Similarly, healthcare in Azerbaijan has become more innovative due to newly introduced telemedicine practices (Mammadova, 2021).

Azerbaijan may learn from international experiences related to the implementation of new programs and strategies to achieve higher levels of innovative output. An examination of these experiences can improve the efficiency of future innovation policies and yield lessons learned from strategic partner countries. For instance, the case of Israel demonstrates new opportunities for improving the innovation ecosystem in Azerbaijan by developing venture funds; human capital; start-up funding; cooperation between the academic, industrial, and governmental sectors; infrastructure support; and international cooperation (Babayev, 2019). Similarly, the case of South Korea can serve as a benchmark if current corruption levels in Azerbaijan can be reduced (YoungChool, 2021).

In line with the United Nations' Millennium Development Goals, improvements in Azerbaijan's innovativeness have led to positive economic outcomes, such as an increase in employment (Habibova and Zeynalova, 2018). Azerbaijan has taken steps to adopt innovative technologies, but the private sector significantly lags behind in the implementation of ICT-driven businesses due to a lack of technological availability, cumbersome financial mechanisms, fear of cybercrime, and other factors (Manafov and Sadigov, 2021). Many enterprises in Azerbaijan have followed traditional business creation strategies, without visibly resorting to innovations (Ashurov, 2020). Lagging innovation in a number of industries have shed light on the importance of increasing state-led innovation policies to promote innovativeness in Azerbaijan in the medium to long term.

\subsection{Georgia}

Georgia is a services-led economy. The number of studies that evaluate Georgia's innovativeness has increased in recent years. For example, Majno et al. (2019) found that industrial design offers fertile ground for the integration of Georgia's historical economic traditions with modern innovations. This supports current positive trends in Georgia's manufacturing sector. According to Shaburishvili and Javakhishvili's (2017) analysis, the innovativeness of Georgian firms is low, and there is a significant gap between the Georgian model of economic development and developed countries' approach to becoming innovative economies. The mismatch between the legal regulation of intellectual property and international copyright standard is one of the main impediments to meeting expected levels of innovativeness at the country level. While Gamsakhurdia (2021) identified similar results among SMEs, Kharaishvili (2020) highlighted the agricultural sector as significantly lacking in innovativeness.

Despite the Georgian Innovation and Technology Agency's coordination of innovative activities countrywide, weak R\&D is the Georgian economy's main obstacle to achieving higher levels of innovative output (Bakhtadze and Danelia, 2020; Chechelashvili, 2017). Majno et al. (2019) also stressed the importance of policies and regulations to guarantee investors' interests, encourage innovation, and upgrade quality standards to align with EU practices. In addition, problems associated with labor markets must be addressed to alleviate labor resource deficiency and develop a more innovative private sector (UNECE, 2020). The private sector's innovative 
outputs are currently insignificant (Abesadze and Burduli, 2018), and cooperation between universities and the private sector in terms of patent applications is extremely low (Jibuti, 2014). Nevertheless, the Georgian Innovation and Technology Agency actively and progressively strengthens the commercialization of innovations, which can potentially serve as a benchmark in the South Caucasus (Erkomaishvili, 2019).

As in Azerbaijan, Georgia has also made progress in social innovations in terms of public service delivery and e-government practices to catch up with leading countries. For instance, Georgia has implemented "community centers" in villages to strengthen the development of rural communities in a more innovative manner (Chikhladze, 2020). Culture and infrastructure impediments are two of the main obstacles in increasing the digitalization of the Georgian economy and achieving a more innovative environment (Maglakelidze, 2020). Moreover, Chiladze (2017) argued that a lack of coordination between government entities to regulate intellectual property rights has significantly delayed the development of Georgia's innovativeness.

Youite et al. (2018) found that standard product and process improvements are not enough to increase profitability and employment and generate competitive advantages in the Georgian economy. The innovation climate of national economies heavily depends on their education system. Therefore, any gaps in education and training may lead to sluggish innovativeness. A study on Georgian schools by Kapanadze (2021) concluded that the transmission of process-oriented skills and capabilities in secondary schools and universities, which usually supports innovative outputs, was lacking. Instead, Georgian education systems largely imparted theoretical and abstract knowledge to students as preparation for the labor market. Although underfinancing was the primary concern with education in the 1990s (Kinkladze and Chitaladze, 2018), Noniashvili (2020) found that the Georgian education sector is ready to employ technological platforms to improve the educational quality.

\section{Data and Methodology}

This paper aims to analyze the relationship between innovativeness, as measured by the Global Innovations Index (or, more simply, the Innovations Index) on a scale from 0 and 100, and selected economic, institutional, and governance-related variables of interest in the countries of the South Caucasus. The Innovations Index includes two sub-indices. The first sub-index is called the "innovation input sub-index" and covers economic aspects related to human capital and research, institutions, infrastructure, market sophistication, and business sophistication to conceptualize the innovative activities in a given country. The second sub-index is called the "innovative output sub-index" and encompasses knowledge and technology outputs and creative outputs.

The data was sourced from the GDP and economic growth, governance and business environment, and innovation measures sections of the Global Economy (2021). The dataset covered the individual country dynamics of Armenia, Azerbaijan, and Georgia. In addition, the country indicators were averaged to estimate the overall region average (also called the "South Caucasus average") to enable a comparative perspective. For indicators such as GDP, etc., the data mainly covered the period between 1990 and 2020. Due to data limitations, the scatter plots in the figure analysis only cover the period between 2011 and 2019. As seen in the abovementioned description of the Innovations Index, its components and sub-indices are difficult to estimate in a longitudinal manner. Thus, the data range was relatively narrow, but it is sufficiently informative for analyzing national innovativeness among the South Caucasus economies.

An Order 2 polynomial trendline approach was used in the scatter plot data visualization process to underline differences between multiple levels of indicators. In other words, the polynomial trendline approach enabled an assessment of the visual relationship between two variables by dividing the dataset into two parts. This division is more efficient than a linear trendline approach for highlighting the link between various levels of the same variable. The polynomial equation is as follows:

$y_{i, t}=\alpha_{0}+\alpha_{1} x_{1(i, t)}^{2}+\alpha_{2} x_{2(i, t)}$

where $y_{i, t}$ is the Y-axis variable (i.e., GDP per capita in current prices, the rule of law index, etc.), $\alpha_{0}$ is the intercept, $\alpha_{1}$ and $\alpha_{2}$ are the coefficients of the quadratic function, and $x_{1}$ and $x_{2}$ are the values of the $\mathrm{X}$-axis variable $i$ at time $t, \mathrm{X}$-axis variable mainly being the Innovations Index. Each scatter plot reports both polynomial trendline equations and $\mathrm{R}$-squared $\left(\mathrm{R}^{2}\right)$ values to check goodness of fit.

Year-over-year growth rates in the Innovations Index were calculated according to the following formula: 
$X_{G R}=\frac{X_{i, t}-X_{i, t-1}}{X_{i, t-1}} \times 100$

where $X_{G R}$ denotes the growth rate of the variable $\mathrm{X}, X_{i, t}$ is the value of the variable in the current year, and $X_{i, t-1}$ is the value of the variable in the previous year.

All calculations and analyses were conducted in Microsoft Excel (version 15.26) on the Mac operating system (OS). There were no missing values in the scatter plots nor in the polynomial trendline analysis; however, other components of the analysis (i.e., figures) showed gaps if any missing value were present in the dataset.

\section{Results}

This section presents the findings of the research.

\subsection{Economic Growth and Innovativeness in the South Caucasus}

The South Caucasus economies entered the 2000s with gradual and consistent economic growth. Until the global financial crisis of 2008-2009, Armenia and Georgia had experienced a multi-year increase in economic growth, as measured by the rate of change of real GDP. Meanwhile, the Azerbaijani economy grew by $34.47 \%$ in 2006 compared to 2005, which represented the highest economic growth in the South Caucasus between 2000 and 2019 and among some other countries (see Figure 1, panel a). However, Armenia's economic growth fell to $6.9 \%$ and $-14.1 \%$ in 2008 and 2009 , respectively, compared to $13.7 \%$ in 2007. Similarly, Georgia's economic growth decreased by 10.16 percentage points and bottomed to $-3.65 \%$ in 2009. Since 2010, growth in the South Caucasus economies has fluctuated. Azerbaijan experienced a sharp decline following the downturn in international commodity markets after 2014-2015.

As measured in current U.S. dollars, GDP data for the South Caucasus shows that Azerbaijan's growth remained low after commodity price slumps in 2014 and 2015 despite being the largest economy in the region (see Figure 1, panel $b$ ). In other words, Azerbaijan's economy was more volatile and exhibited distinct highs and lows, while Armenia and Georgia had more stable and sustainable economies despite being smaller countries.

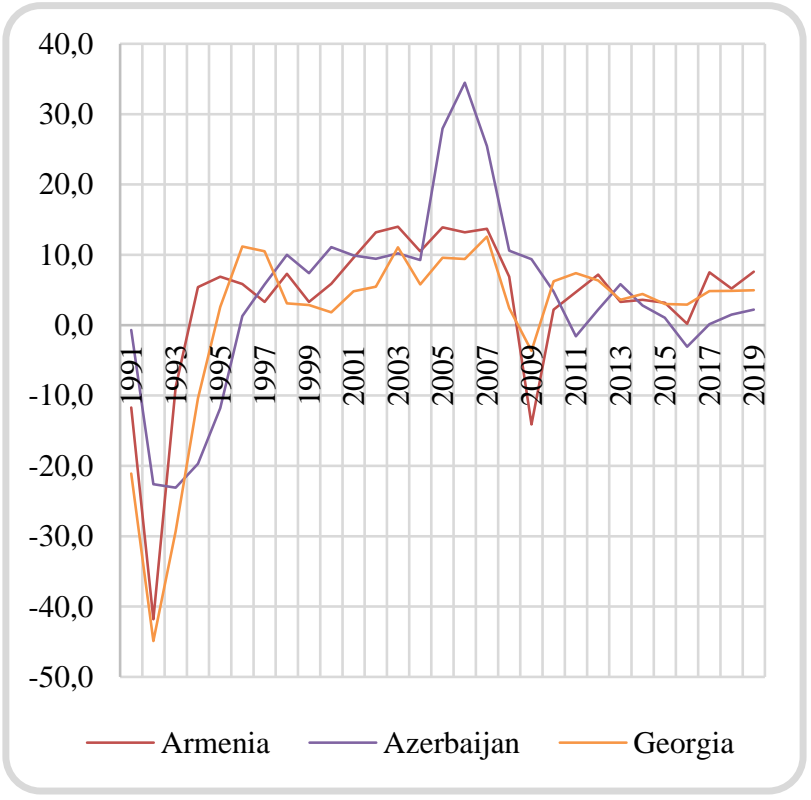

a. Economic growth (rate of change of real GDP), in percent

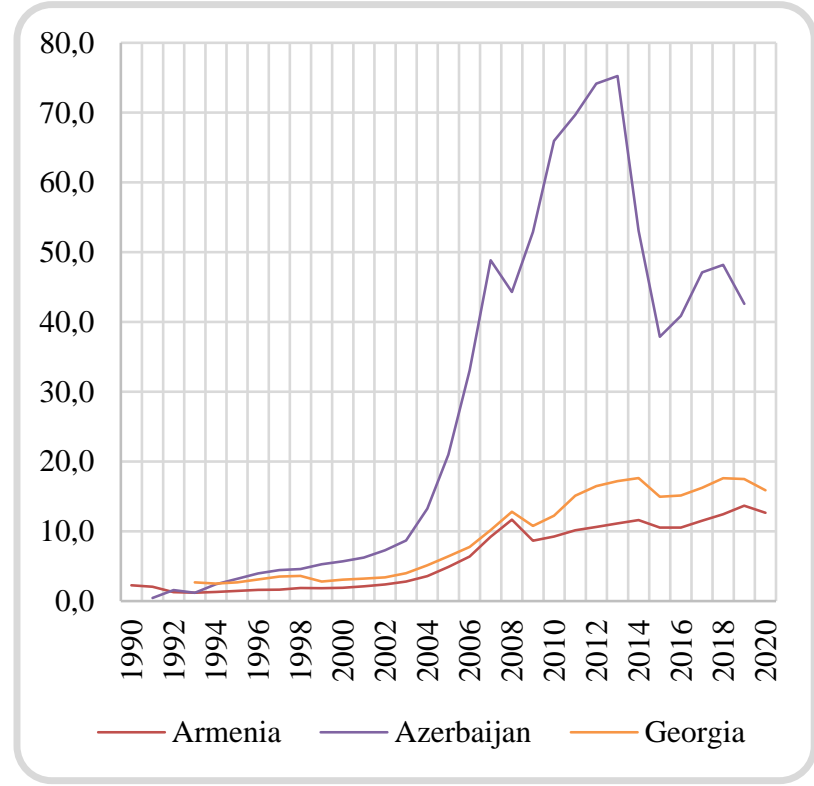

b. GDP in billions of U.S. dollars

Figure 1. Economic growth in the South Caucasus, 2000-2019

Source: The Global Economy (2021). 
Although the South Caucasus was well-placed to develop the essential factors that drive innovativeness during their rapid economic growth, individual countries have shown discrepancies in their commitment to developing the key components of innovativeness. Although data about R\&D expenditures is limited in Georgia's case, Azerbaijan and Armenia had similar annual R\&D expenditures as a percentage of GDP between 2009 and 2018: $0.25 \%$ and $0.24 \%$, respectively. From 1996 to 2003, Azerbaijan's R\&D expenditures exceeded Armenia's, but Armenia began to surpass Azerbaijan in 2005. In 2015, Georgia led in R\&D expenditures as a share of GDP in the South Caucasus, with 0.32\%; however, there was a slight decline in 2016 and 2017.

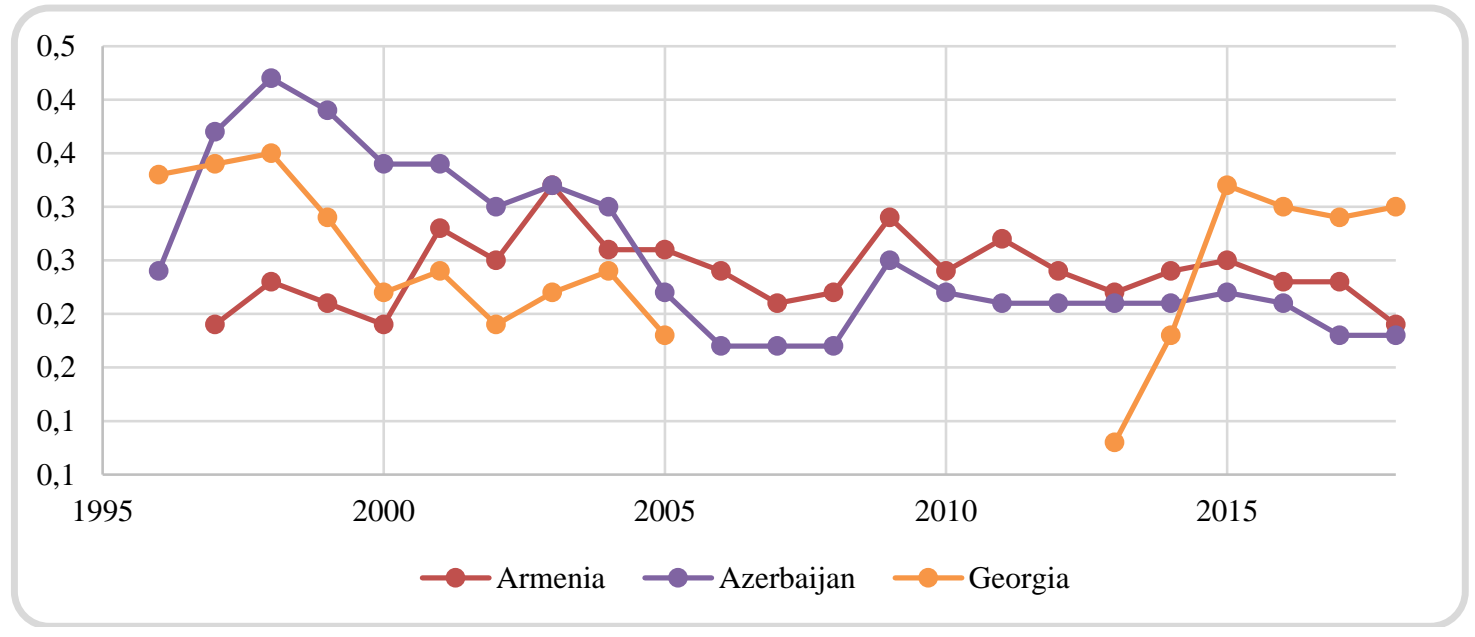

Figure 2. Research and development expenditures as a percentage of GDP

Source: The Global Economy (2021).

Meanwhile, ICT exports are the most direct and common way to obtain an overview of innovativeness dynamics in a country. Armenia's ICT exports were high between 2007 and 2013 and accounted for approximately $1 \%$ of total exported goods; however, starting from 2013, Armenia's ICT exports declined to under $0.5 \%$. Georgia's ICT exports have been rising since 2006 and increased by $94.29 \%$ in 2015 compared to 2006 (see Figure 3, panel a). However, they gradually slowed to 0.4\% in 2016, which is on par with pre-2012 levels. In Azerbaijan, ICT exports occupy a negligible share of the economy at $0.02 \%$ per annum. As a share of total exported goods, ICT exports reached their peak in 2000 at $0.14 \%$. In addition, as oil and natural gas exports occupy the largest shares in the Azerbaijani exports, all other export categories significantly get pushed down in terms of percentage of total exports.

Furthermore, high-technology exports between 2000 and 2019 showed a consistent and upward trend in Armenia (see Figure 3, panel $b$ ). This trend has accelerated since 2015, reaching a historically high value of USD 45.65 million in 2019. Similarly, Azerbaijan's high-technology exports increased by 57.56\% in 2019 compared to 2016. Notably, Azerbaijan achieved the highest value of exported high technology products in the South Caucasus at USD 45.37 million, 73.4 million, and USD 37.91 million in 2012, 2013, and 2014, respectively. Although high-technology exports saw a downward trend from 2015 (USD 39.24 million) to 2019 (USD 19.35 million), Georgia managed to achieve nearly USD 40 million in high-technology exports between 2009 and 2015.

As a share of overall manufactured exports, high-technology exports in Azerbaijan substantially increased to $13.78 \%$ in 2013 from lows such as $1.02 \%$ in 2009; however, this growth was short-lived (see Figure 4, panel $a$ ). Azerbaijan's high-technology exports dropped to $2.85 \%$ in 2016 , then began to moderately increase $(4.35 \%$ in 2018, and 4.96\% in 2019). While Georgia experienced a gradual increase in high-technology exports as a share of manufactured goods between 2011 and 2015 (from 1.51\% to 6.29\%), Georgia is the only country in the South Caucasus where this figure has seen a downward trend since 2016, reaching a low of $2.57 \%$ in 2019 . Lastly, the development of high-technology exports as a share of manufactured goods has been more sustainable in Armenia, accelerating from 1.14\% in 2007 to $9.79 \%$ in 2019 without any notable slowing. 


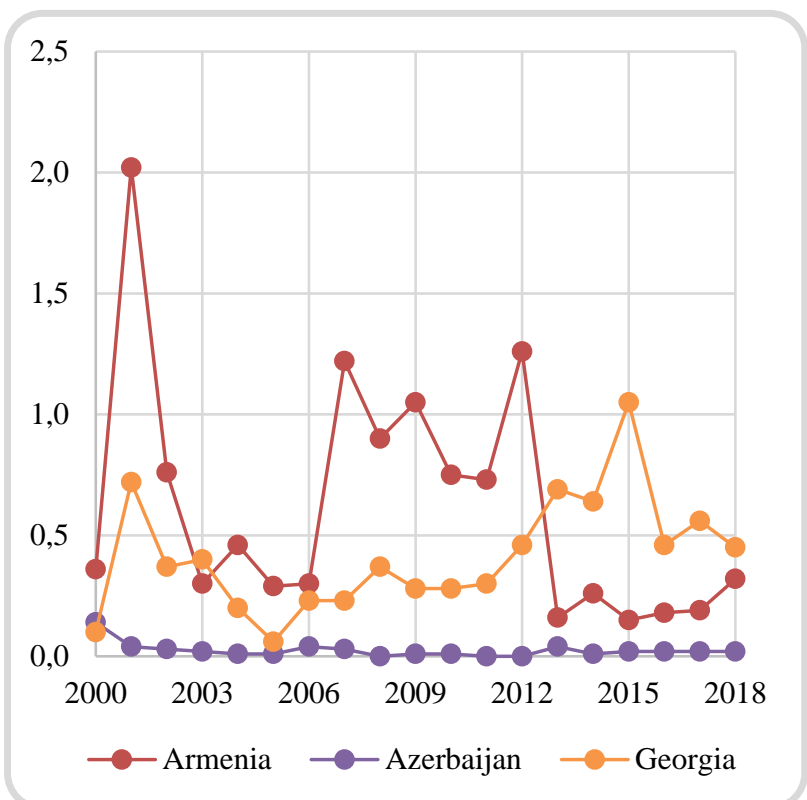

a. Information technology exports as a percentage of total goods exports, 2000-2019

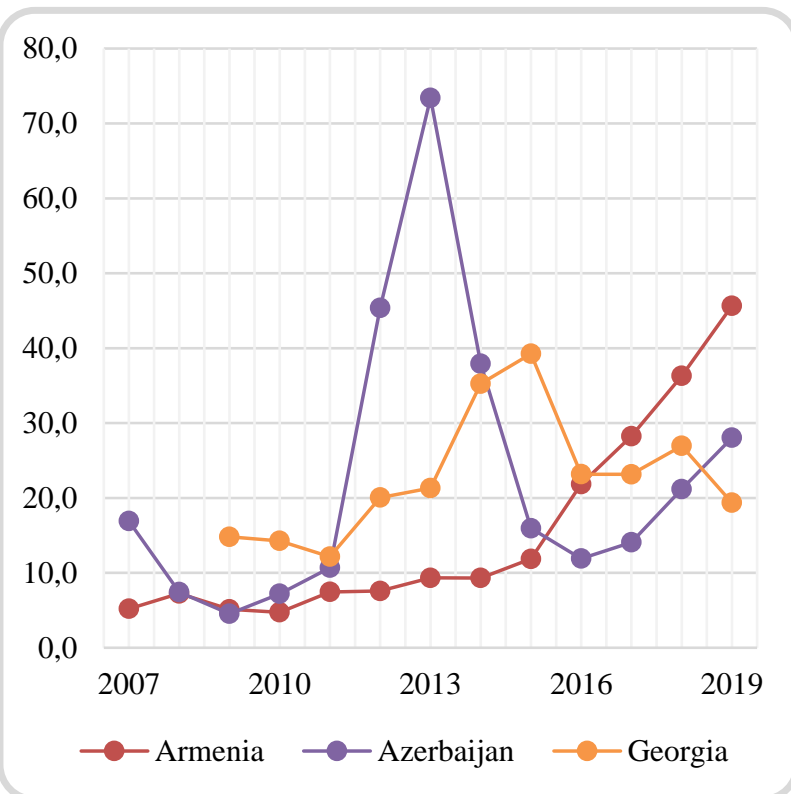

b. High-technology exports in millions of U.S. dollars, 2007-2019

Figure 3. Information and high-technology exports in the South Caucasus countries.

Source: The Global Economy (2021).

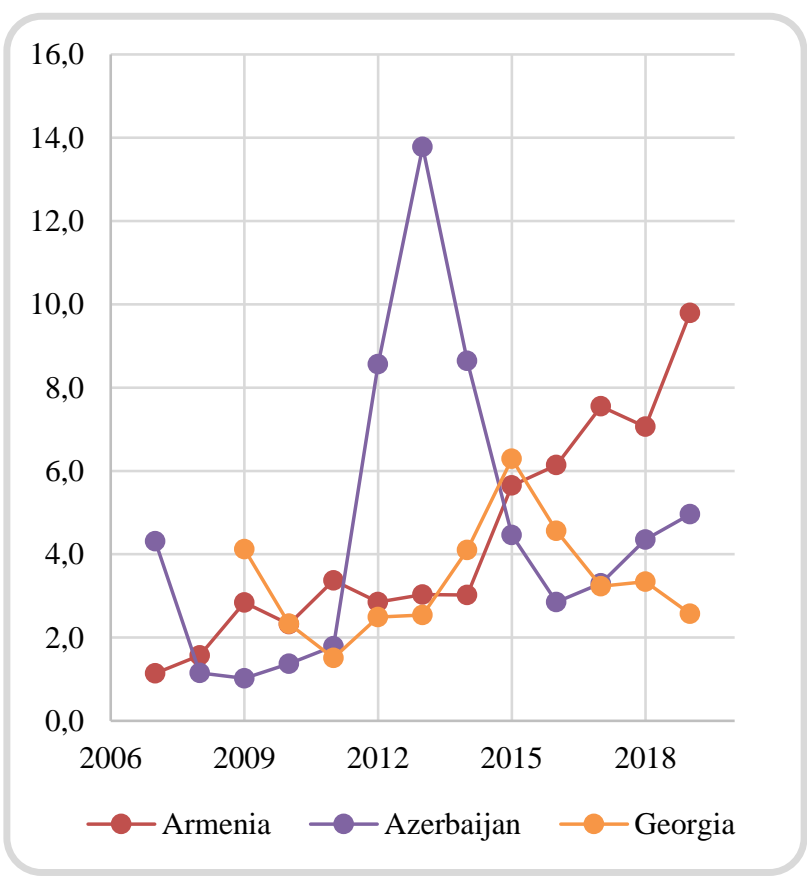

a. High technology exports as a percentage of manufactured exports, 2007-2019

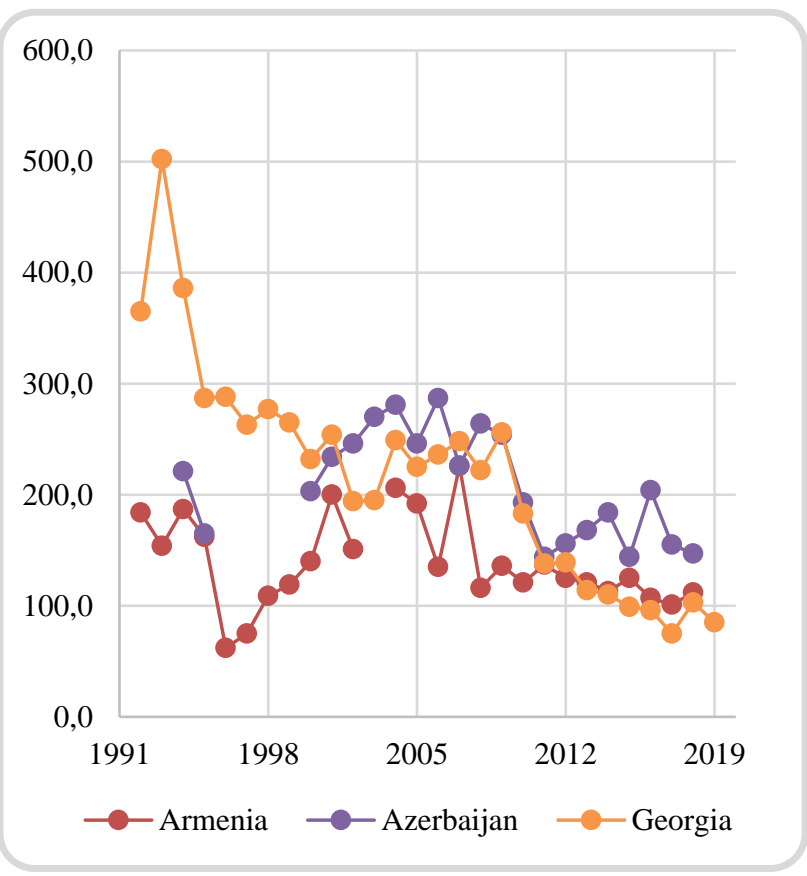

b. Number of patent applications by residents, 2000-2019

Figure 4. High-technology exports as a share of manufactured goods and number of patent applications in the South Caucasus

Source: The Global Economy (2021). 
Meanwhile, all of the South Caucasus countries showed a downward trend in the number of patent applications by residents between 2000 and 2019 (see Figure 4, panel $b$ ). Azerbaijan has outperformed both Armenia and Georgia in number of patent applications since 2002, while Armenia began to outpace Georgia in 2012. Notably, Georgia led in the number of patent applications in the 1990s despite some steep declines, but it has failed to retain this status. Similarly, all of the South Caucasus countries saw a stable number of patent applications between 2002 and 2009; however, they have failed to reverse sharp downward trends in later years.

\subsection{Intraregional Comparisons Using the Polynomial Trendline Approach}

Figure 5 shows the innovativeness of individual countries in the South Caucasus and the region as a whole over a 10-year period (2011-2020). Overall, innovativeness showed a negative linear trend in Armenia and Azerbaijan and a positive linear trend in Georgia. This trend was also negative for the region. Moreover, Azerbaijan was the least innovative economy throughout the period under analysis, while Armenia achieved most of the highest values in the Innovations Index, except in 2018 and 2019. More recently, Georgia has led in innovativeness with index values of 35 and 37 in 2018 and 2019, respectively.

Armenia has rapidly developed its innovativeness since 2011 and achieved a peak of 37.6 in 2013. Meanwhile, it reached its lowest value of 32.8 in 2018. Although the Innovations Index improved by approximately $3.7 \%$ in 2019 compared to 2018, the value declined by $4.12 \%$ in 2020 compared to 2019.

The second most innovative country in the South Caucasus is Georgia. Between 2011 and 2013, the country experienced noticeable increases in innovativeness, but this trend weakened between 2013 and 2015. The Innovations Index value peaked at 37 in in 2019, which represents the second-highest value since 2011 (the highest being Armenia's record of 37.6 in 2013). However, Georgia experienced a sharp decline of $14.05 \%$ in innovativeness in 2020 compared to 2019.

Compared to the volatile and fluctuating Innovations Index values in Armenia and Georgia, Azerbaijan has shown stable but low innovativeness between 2011 and 2020. In 2011, Azerbaijan had an innovativeness value of 29.2; this rose to 30.4 in 2012 and declined to 29 in 2013. Between 2014 and 2019, Azerbaijan achieved an innovativeness value of 30.05 per annum. However, as in Armenia and Georgia, innovativeness in Azerbaijan sharply declined in 2020 (by $9.93 \%$ compared to 2019).

The regional average of innovativeness fluctuated between 2013 and 2014 but experienced a sharp fall in 2020.

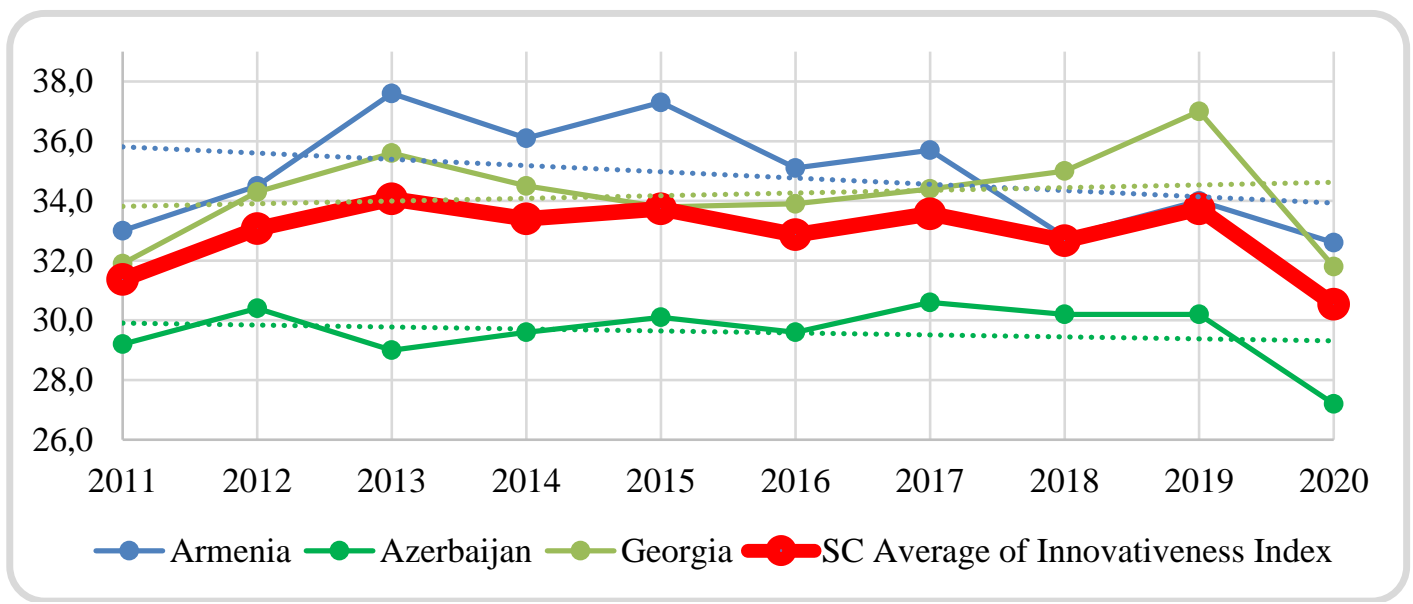

Figure 5. Innovations Index in the South Caucasus, 2011-2020

Source: The Global Economy (2021).

Figure 6 illustrates the year-over-year growth rate of innovativeness in the South Caucasus. The Innovations Index in all countries and the regional average fluctuated between 2012 and 2020 . Over a nine-year period, Armenia and Georgia saw noticeable growth rates (e.g., 11.6\% and 13.9\% in 2015 in Georgia and Armenia, respectively). Notably, innovativeness grew by 13\% in Armenia in 2015 and 16\% in Georgia in 2019. 
Conversely, growth rates for innovativeness were more restrained in Azerbaijan compared to Armenia, Georgia, and the South Caucasus average; values such as $0.7 \%$ in 2013 and 1.4\% in 2016 were the lowest in the region. In addition, the sharpest decline in innovativeness growth occurred in 2020 in Azerbaijan: a decrease of $6.8 \%$ compared to 2019. By comparison, Armenia and Georgia experienced decreases of $2.7 \%$ and $0.3 \%$, respectively, over the same period.

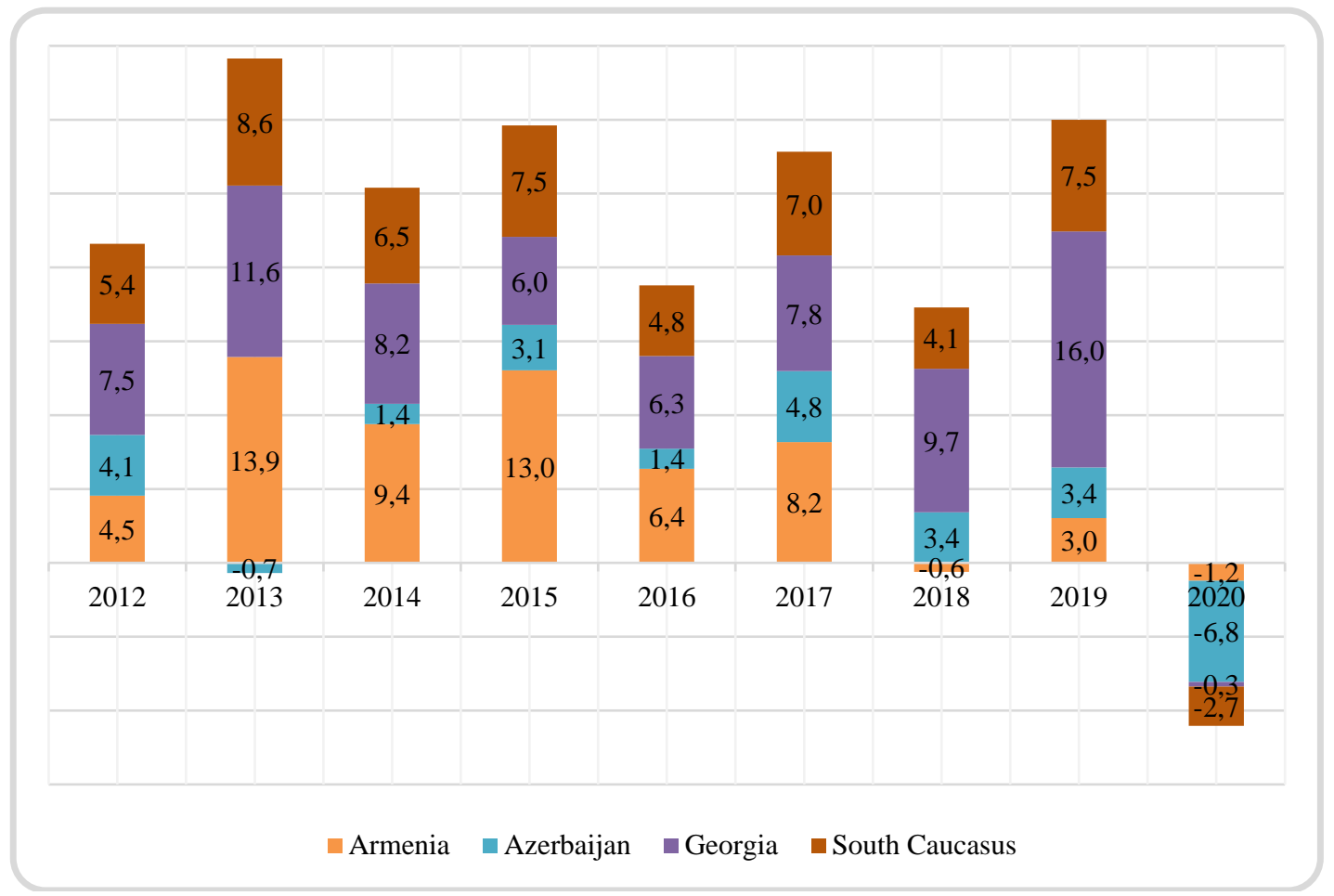

Figure 6. Year-over-year growth rates for innovativeness in the South Caucasus economies (in percent), 2012-2020

Source: The Global Economy (2021).

Usually, GDP per capita is a proxy for economic wealth and overall welfare. As an aggregate indicator, it can also be associated with innovativeness; as the country becomes richer, innovativeness can be improved through higher resource allocations. When applying this idea, the only positive polynomial trendline can be observed in Georgia's case (see Figure 7). Meanwhile, innovativeness in Armenia is negatively associated with GDP per capita after the latter reaches USD 3,700; the same applies to Azerbaijan after GDP per capita reaches USD 5,500. In addition, Armenia's fall in the Innovations Index is more severe compared to Azerbaijan in relation to GDP per capita dynamics. Although individual countries in the South Caucasus demonstrate different trends with regard to the association between innovativeness and GDP per capita, the regional average shows that there is a positive relationship between these two variables after GDP per capita reaches USD 4,561; this indicates more optimistic expectations based on the relationship between innovativeness and economic growth in the long term.

The rule of law index is another important dimension of innovativeness that can be associated with greater innovative activities if constant and systematic improvements are observed in the bureaucratic apparatus and state-building. The rule of law is heavily discussed and has been attributed to many success stories. Figure 8 shows that only the polynomial trendline for Azerbaijan is an absolute positive between the rule of law and innovativeness indices, while the same association sharply drops in Armenia's case and Georgia presents slightly smooth drops after certain thresholds. 

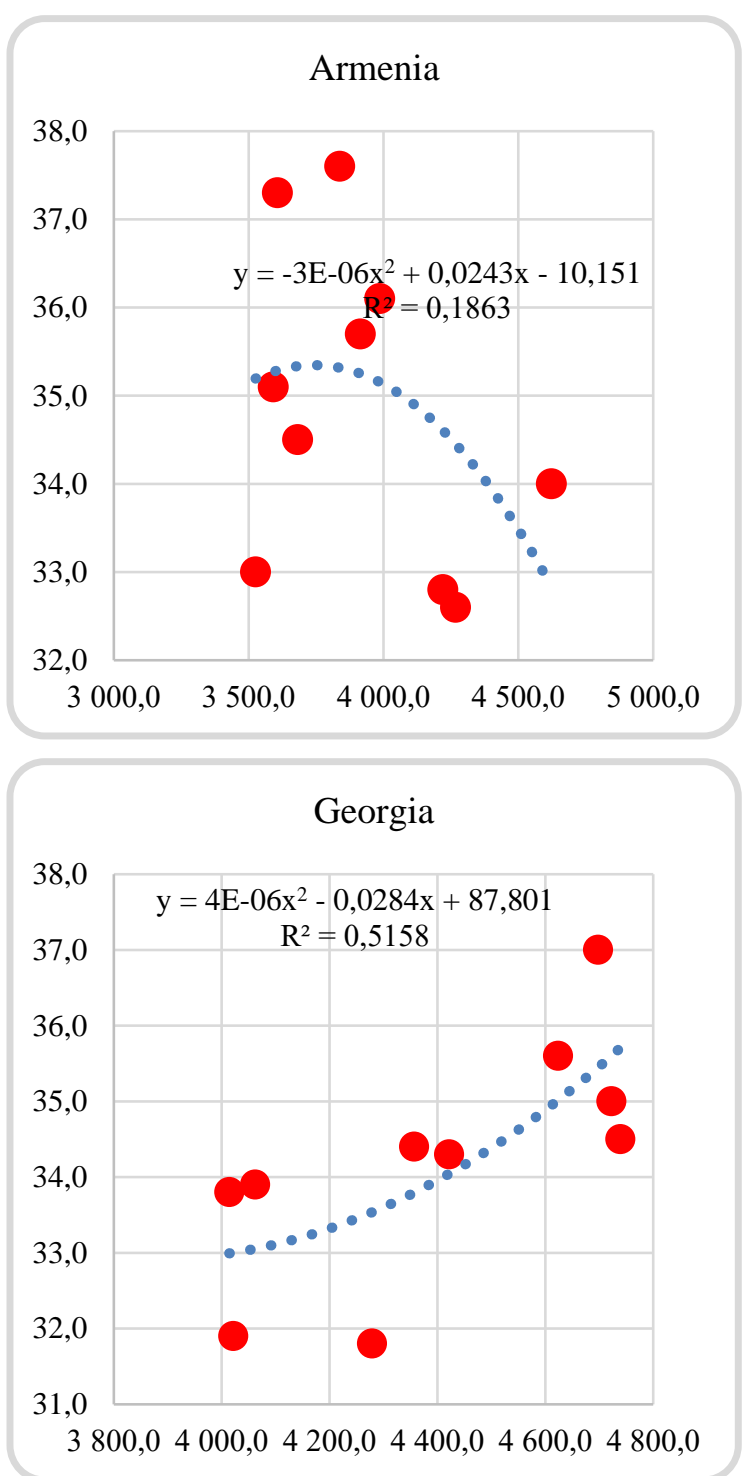
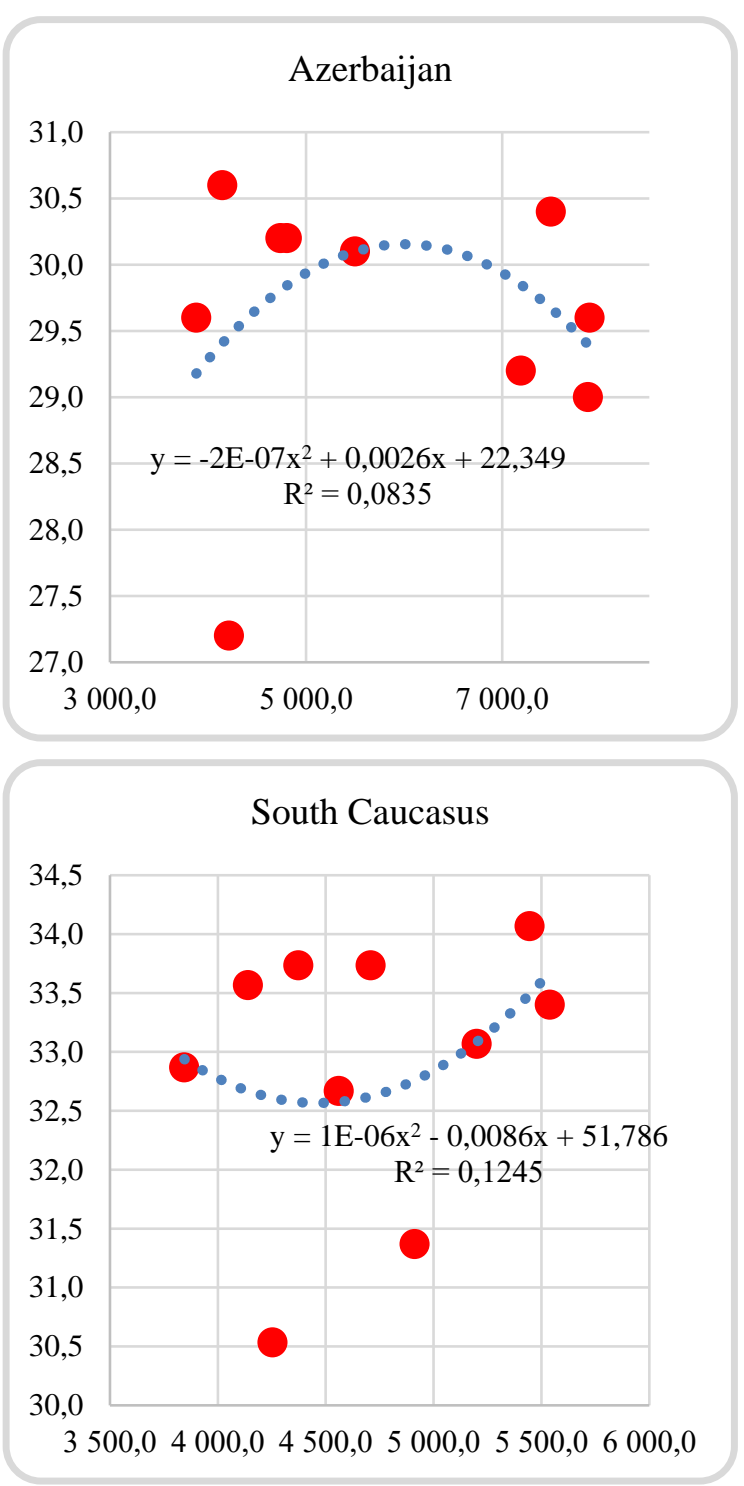

$3500,04000,04500,05000,05500,06000,0$

Figure 7. GDP per capita in current U.S. dollars (X-axis) and the innovativeness index (Yaxis) in the South Caucasus, 2011-2020

Source: The Global Economy (2021).

Moreover, the association between the rule of law and innovativeness indices shows clear clusters in the above scatter plots. In other words, Armenia's innovativeness significantly improved when the rule of law index developed in the range of -0.5 and -0.3 ; however, between -0.2 and 0.0 , the Innovations Index fell from 35.70 to 32.80 index values. In Azerbaijan's case, the Innovations Index increased from only 29.0 to 30.60 index values despite despite significant improvements in the rule of law index (from -0.72 to -0.52). Meanwhile, Georgia's innovativeness overwhelmingly stuck and followed a downward trend (between 33.80 and 35 index values) when the rule of law index was between 0.19 and 0.38 .

In general, most data points related to the South Caucasus region were concentrated between -0.36 and -0.09 for the rule of law index and 32.67 and 33.73 for the Innovations Index. This shows a mixed association between rule of law and innovativeness at the regional level. Innovativeness did not improve with stronger rule of law, but sharp improvements in innovativeness (from 31.37 to 34.07) were observed when rule of law rose from 0.48 to -0.36 . 

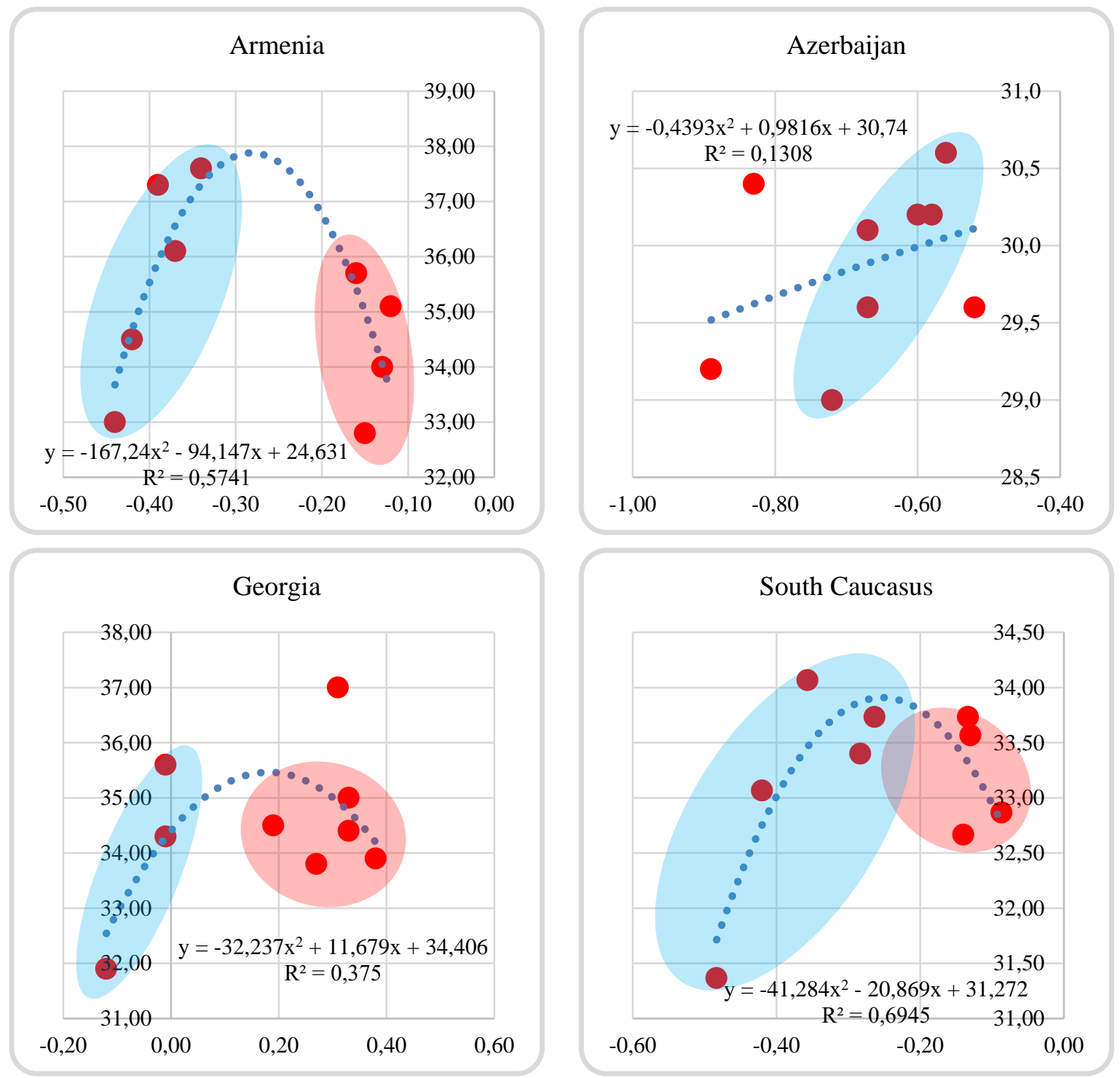

Figure 8. Rule of law index (X-axis) and the innovativeness index ( $\mathrm{Y}$-axis) in the South Caucasus, 2011-2019

Source: The Global Economy (2021).

The connection between property rights and innovation is the other most discussed channel after the role of rule of law when it comes to the key drivers of national innovativeness. From the scatter plot depicted in Figure 9, it can be argued that the property rights index does not drive national and regional innovativeness. In Azerbaijan, Georgia, and the South Caucasus overall, innovativeness developed without any substantial progress in property rights. In other words, Azerbaijan's innovativeness slightly increased from 29.0 to 30.4 while the property rights index remained stable between 20 and 25. Similarly, although Georgia experienced a 3.7-point increase in the Innovations Index, the property rights index stayed between 40 and 45. Overall, innovativeness in the South Caucasus improved from 31.37 to 34.07, while property rights remained between 30 and 33.3. Furthermore, Armenia was the only country where a significant negative relationship was found between property rights and innovativeness. In Azerbaijan, Georgia, and the South Caucasus, this relationship became negative only when the property rights index reached a high value (e.g., 40 or 50); however, most data points were clustered along the positive side of the association. 

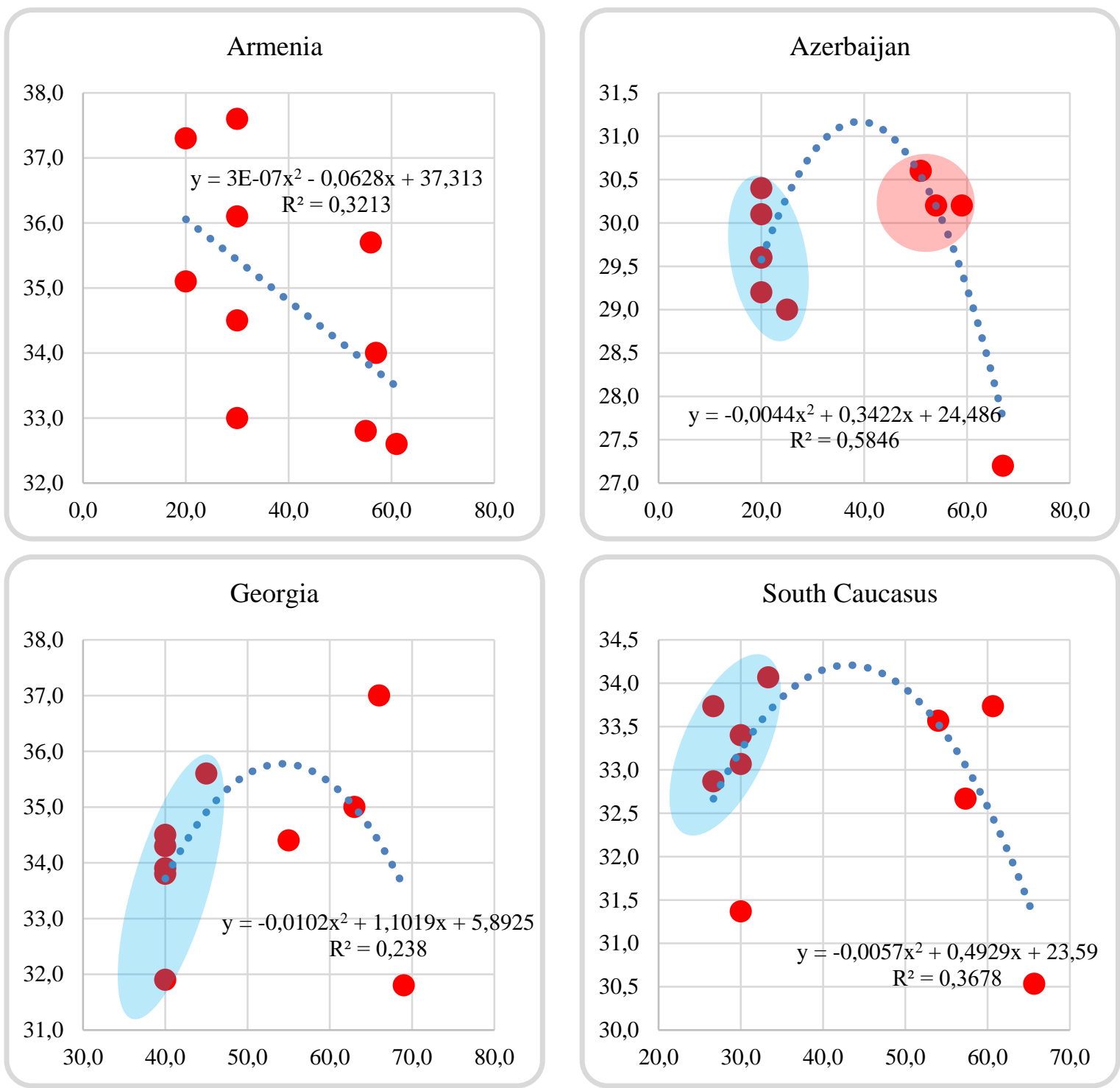

Figure 9. The property rights index (X-axis) and the Innovations Index (Y-axis) in the South Caucasus, 2011-2020

Source: The Global Economy (2021).

Economic freedom is another factor that may help countries become more innovative and thus more competitive in international markets. Therefore, a positive association between economic freedom and innovativeness is expected. However, data from Armenia and the South Caucasus average contradict this claim, while greater economic freedom seems to lead to innovativeness in the cases of Azerbaijan and Georgia. The slope of the polynomial trendline is flat for Georgia but steeper for Azerbaijan; this indicates rapid responses of increase in innovativeness to increase in economic freedom in the case of Azerbaijan. 

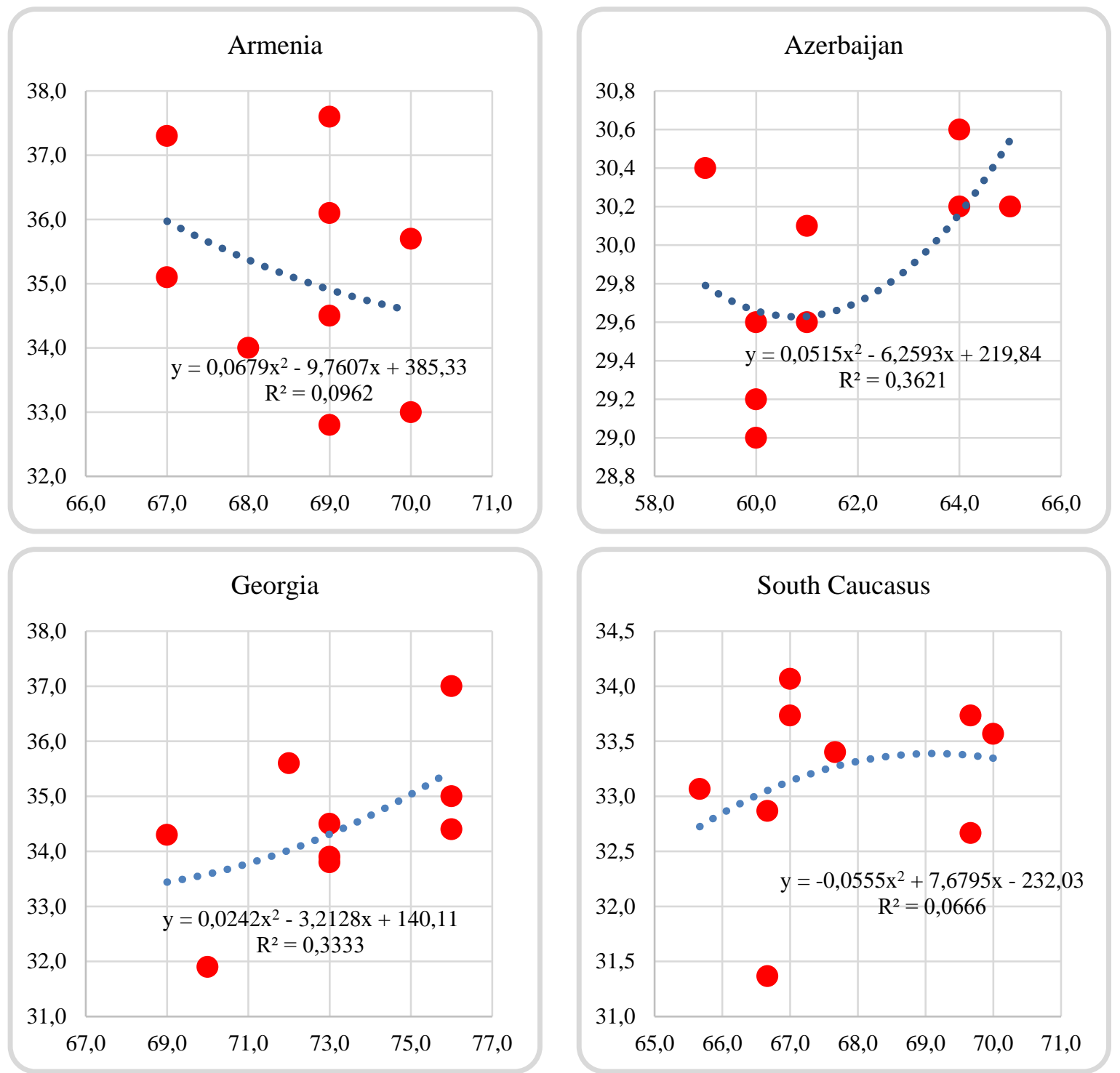

Figure 10. The economic freedom index (X-axis) and the innovativeness index (Y-axis) in the South Caucasus, 2011-2019.

Source: The Global Economy (2021).

Lastly, a country is considered to be more innovative as its high-tech or ICT exports increase. However, this argument does not hold true for the South Caucasus as a whole. The main data points related to the association between ICT exports and innovativeness are clustered along the negative part of the polynomial trendline. Meanwhile, ICT exports for Armenia are concentrated between $0.15 \%$ and $0.32 \%$ and innovativeness ranges between 32.80 and 37.60 after a downward trend (see Figure 11). However, for Azerbaijan and Georgia, increases in ICT exports followed improvements in innovation, as most of the data points are positioned in the upward part of the polynomial trendline. 

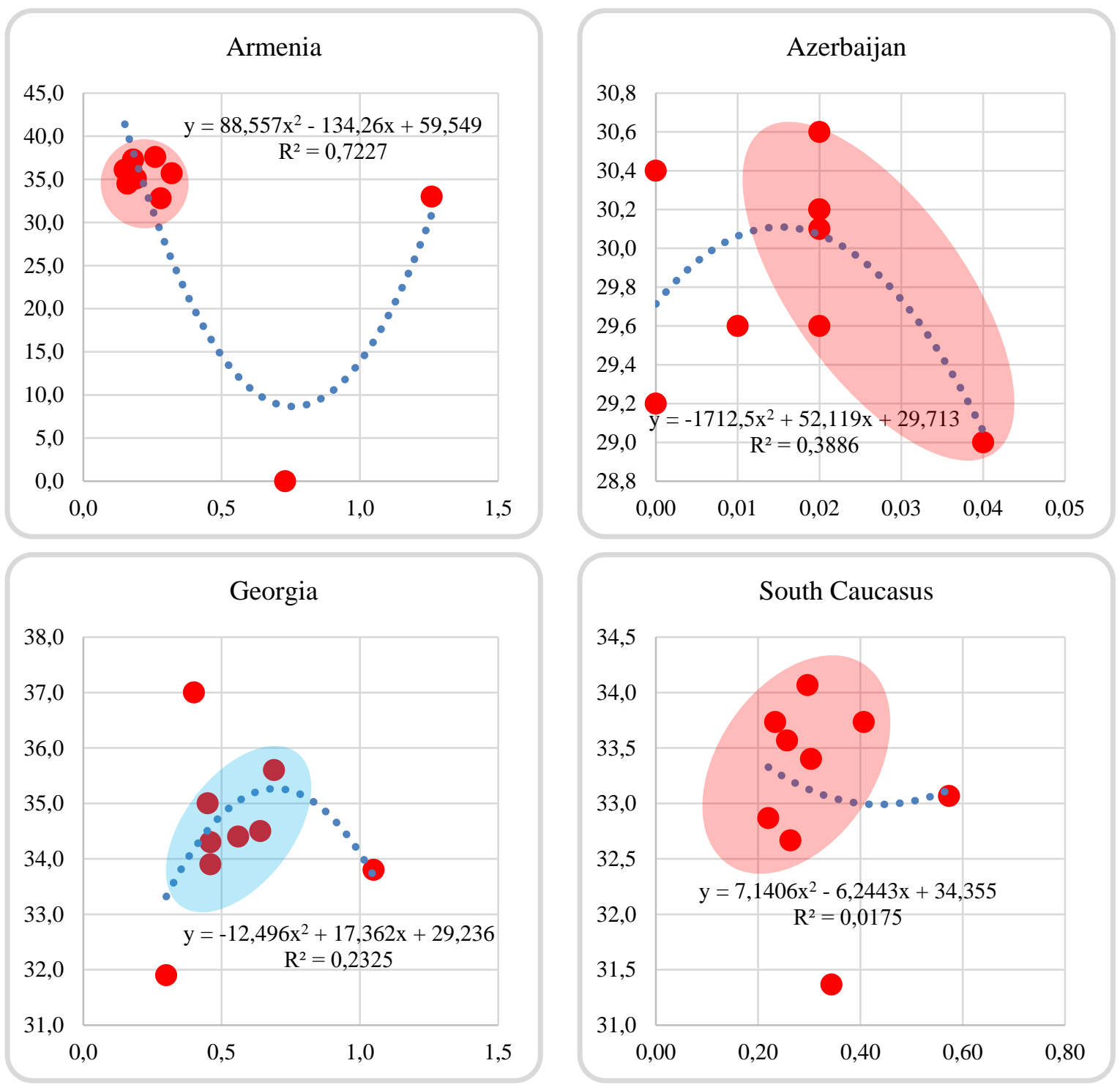

Figure 11. Information communication technology exports (X-axis) and the Innovations Index (Y-axis) in the South Caucasus, 2011-2019

Source: The Global Economy (2021).

\section{Discussion}

Rapid transitions, Azerbaijan's oil boom, and increased integration have improved key economic and innovation indicators between 1994 and 2008 in the South Caucasus. The region's innovativeness has fluctuated, and negative trends have been observed in components of innovativeness (e.g., patent applications). In addition, population decline, aging, and the impact of the COVID-19 in the post-Soviet space make high rates of economic growth impossible for the near future. However, new reforms that aim to increase total factor productivity, investments, and sectoral restructuring may allow Former Soviet Union (FSU) countries to reduce their dependence on commodities and make the green energy transition (Dabrowski, 2020).

Although the global economy and its main components suffered as a result of the COVID-19 pandemic in 2020, the positive trend of national innovativeness in Georgia continued; however, the same cannot be said for Azerbaijan and Armenia (see Figure 5). Since 2012, innovativeness has fluctuated in the South Caucasus, and notable growth and development have not been achieved. Moreover, the key determinants of innovativeness, 
such as economic growth, rule of law, property rights, economic freedom, and ICT exports, have had different effects on national innovativeness in each country.

The analysis showed that economic growth and innovativeness go hand-in-hand in Georgia and in the South Caucasus as a whole, while rule of law contributes only partially to innovativeness. In Armenia, GDP per capita is more negatively associated with innovativeness than in Azerbaijan, but Azerbaijan is the only country in the region where rule of law is strongly and positively associated with national innovativeness.

A similar picture emerges in terms of the role of property rights; innovativeness in the South Caucasus countries benefits from improvements in property rights to a lesser extent compared to accumulated wealth. Thus, the South Caucasus countries should follow a blended policy approach that not only focuses on economic or institutional factors but also political and governance factors to stimulate growth in innovativeness.

Higher innovativeness should lead to increased output in innovative economic sectors, such as ICT. However, this expected relationship was not observed in individual countries and the South Caucasus as a whole. The results of this paper illustrate that ICT exports and innovativeness in Armenia remained stable, without noticeable improvements or declines. In Georgia, however, increasing ICT output was accompanied by higher innovativeness. In Azerbaijan, ICT output was lower than that of Armenia, Georgia, and the South Caucasus average. Generally, the relationship between ICT output and innovativeness was negative for the region as a whole.

The steep decline in the number of patent applications in Azerbaijan and Georgia since 2008 implies that the Azerbaijan oil boom imbued the government with a certain level of confidence and led it reduce the stimulative actions necessary to boost R\&D. Since the Georgian economy also benefited from Azerbaijan's oil and natural gas projects, this may also hold true for Georgia. However, Azerbaijan has notably recovered from the severe downward trend in patent applications since 2012, but overall patent applications in Georgia reached a historically low number of 75, which was 30\% lower than in Armenia and 63.2\% lower than in Azerbaijan in 2012. Dabrowski (2020) argued that market-oriented reforms in FSU countries stopped in the mid-2000s due to the completion of the transition from a command economy to a market economy. Therefore, stagnant market reforms may have led to lower innovative outputs (as reflected by the number of patent applications) compared to the active phase of the transition process.

Intellectual property rights fuel international trade and play a pivotal role in ensuring the continuation of creative and innovative activities (Akkoyunlu, 2013). However, the results of the current paper indicate that the property rights and innovativeness indices were not associated in the South Caucasus. In other words, innovativeness did not respond to changes in property rights in the South Caucasus countries; in Armenia's case, there was even an inverse relationship between these two variables. Therefore, the current exploratory study evokes an ongoing debate in economics. Intellectual property rights or property rights may be beneficial to protect the innovators; however, economic debates also point to the issues related to protecting yesterday's winners for a long time, not allowing the emerging innovators to speak up (Morck and Yeung, 2001). Accordingly, a sole assumption of the good outcome of the property rights protection by the government does not apply in every country, especially when market failures and economic productivity and efficiency have not been achieved. Furthermore, a closer analysis of property rights, including intellectual property rights, must be conducted to shed light on their relevance to innovativeness in the South Caucasus.

Global markets stimulate innovativeness by creating opportunities to use innovations overseas (Morch and Yeung, 2001). The analysis of the South Caucasus appears to support this claim, as a mainly positive relationship was found between economic freedom and innovativeness (except in Armenia). Only the Azerbaijani economy shows a significant and positive relationship between economic freedom index and innovativeness. In Georgia, the marginal benefit of economic freedom was lower than in Azerbaijan. In Armenia, economic freedom and innovativeness were negatively associated. Overall, economic freedom in the South Caucaus plateaued between 2011 and 2019. 
In the Azerbaijani case, the positive association between economic freedom and national innovativeness may be fruitful for developing the business environment and entrepreneurship if challenges related to Dutch disease and job creation can be solved (Sadik-Zada et al., 2021; Sadik-Zada, 2021). Particularly with regard to structural improvements, Azerbaijan may benefit from more sustainable social policies (Aliyeva et al., 2021) and become a less risky country to cooperate with (Gong and Li, 2021). While Sadik-Zada et al. (2019) argued that the transmission of the resource curse and de-industrialization is a multi-sectoral phenomenon, diversification may not guarantee low levels of manufacturing shrinkage in a resource-rich country. The positive and noticeable association between economic freedom and innovativeness in Azerbaijan is promising, compared to other countries in the South Caucasus.

In Azerbaijan's case, it is notable that the absolute and positive association between innovativeness and rule of law and innovativeness and economic freedom shed light on specific channels that can be strengthened through state policies and programs to incentivize innovative outputs. Meanwhile, in Armenia's case, the absolute and negative association between property rights and economic freedom was surprising. Usually, Armenia and Georgia score highly in international rankings of institutional and political measures, while Azerbaijan lags behind its neighbors. However, the findings from this study show that the countries' international rankings do not provide crucial information on innovation and its key drivers. In other words, a high score does not necessarily mean that the rest of the economic indicators benefit from the achieved levels. Stated alternatively, if the impact of institutional variables is low, other parts of the economy grow less even though institutional, or governance indicators improve. Thus, it is important to identify the precise channels that impact innovativeness in the South Caucasus. Economic structures and institutional endowments differ from country to country, which also shape the average in the region. While the Azerbaijani economy is oil-based, the Armenian economy is extractives-based and the Georgian economy is services-led. Political realities and regime types shape the enabling environment and determine whether innovations will emerge or fail due to inadequate commercialization. In countries such as Azerbaijan, the state plays an important role in stimulating innovation, especially technological innovation (Sulyemanli, 2020). Without national innovation infrastructures, certain economic sectors in the South Caucasus are vulnerable to crisis due to a high share of foreign technologies, as evidenced by the case of Azerbaijan (Aliyeva, 2020).

The main limitations of the study are its descriptive nature and small sample size for the time series data. Moreover, the lack of alternatives for measuring innovativeness in the South Caucasus - such as other indexes similar to the Innovations Index - was another limitation. More work is needed to unravel the country-specific conditions of innovativeness and region-level aggregation in the South Caucasus to determine optimal policies for stimulating innovative activities. To this end, a quantitative-only approach seems to be limited but relevant enough to construct alternative indices of national innovativeness in the South Caucasus. Additional empirical models and examinations of innovativeness of the South Caucasus may significantly contribute to the literature. Meanwhile, qualitative research methods are expected to yield grounded explanations of the variables of interest and uncover the views of both industry experts and academic researchers on the future innovativeness in the South Caucasus. Furthermore, political regimes, cultural endowments, and inherited Soviet resources are essential components of innovativeness in the region that remain unaddressed in mainstream economic research.

\section{Concluding Remarks}

This paper aims to explore the relationship between key economic and institutional variables and innovativeness in the economies of the South Caucasus. To this end, ongoing trends and discussions were covered in a literature review, and the Innovations Index in Armenia, Azerbaijan, Georgia, and the region as a whole was examined through figure analysis using a polynomial trendline approach. The main results of the figure analysis can be summarized as follows:

- Innovativeness in the South Caucasus grew in Armenia and Georgia between 2011 and 2020; this applied to a lesser extent in Azerbaijan. 
- For Georgia and the South Caucasus as a whole, innovativeness grew with economic prosperity (as measured by GDP per capita). However, the direction of this association differed for Armenia and Azerbaijan.

- Improved rule of law leads to higher innovativeness according to the figure analysis of the current paper. However, innovativeness in Armenia, Georgia, and the South Caucasus as a whole did not increase as rule of law improved.

- For the South Caucasus as a whole, improvements in property rights were associated with increases in innovativeness. However, results were more ambiguous for individual countries, as data points were almost equally distributed along the positive and negative parts of the polynomial trendline.

- Greater innovativeness followed a rise in economic freedom in Azerbaijan and Georgia, but not in Armenia and the South Caucasus as a whole.

- In Azerbaijan and Georgia, ICT exports are associated with more innovativeness, but this did not apply for Armenia and the region overall despite high performance in Armenia's ICT manufacturing and exports.

The South Caucasus countries must follow a more coordinated approach to tackle challenges related to individual components of innovativeness to achieve innovation-led economic growth and development. A traditional approach to analyzing innovative activities in the South Caucasus may not be fruitful due to the countries' incomplete transition from command economies to market economies-even if many experts consider the transition period as finished-market and institutional failures, and industry policy matters. Moreover, as a region, the South Caucasus must overcome significant differences between countries to attract the attention of large economic powers such as China and the EU and to integrate into GVCs.

As a modern economic reality, innovativeness is the basis of sustainable long-term economic growth and enables countries to cultivate a competitive advantage. If innovativeness is low, a country's competitiveness will suffer, as evidenced by the Western Balkan countries (Despotovic, 2014). The South Caucasus offers an interesting case study, as the region encompasses various economic and political systems that may effect innovativeness. Although Azerbaijan's digital projects, such as the Trans-Eurasian High-Speed Information Highway (TASIM), the International Cable System Europe-Persia Express Gateway (EPEG), and the Eurasian Connection Alliance (EuraCA), increase opportunities for innovation, private sector participation remains low, which creates various obstacles to full collaboration at the national economy level (Guseynov et al., 2021). Moreover, Georgia must actively strengthen its innovation potential through state aid to achieve long-term, sustainable, and innovative business capabilities (Takaladze, 2017). In addition, the role of the state must be rethought in Armenia, as there is a significant mismatch between the education system's output and labor market demands.

Funding: self-funded.

Author contributions: conceptualization, Ibrahim Niftiyev; methodology, Ibrahim Niftiyev; software, Ibrahim Niftiyev, Nargiz Yagublu and Narmin Akbarli; validation, Nargiz Yagublu and Narmin Akbarli; formal analysis, Ibrahim Niftiyev, Nargiz Yagublu, and Narmin Akbarli; methodology, Ibrahim Niftiyev; investigation, Ibrahim Niftiyev, Nargiz Yagublu, and Narmin Akbarli; resources, Ibrahim Niftiyev, Nargiz Yagublu, and Narmin Akbarli; writing-original draft preparation, Ibrahim Niftiyev, Nargiz Yagublu, Narmin Akbarli; writingreview and editing, Nargiz Yagublu, and Narmin Akbarli; visualization, Ibrahim Niftiyev; supervision, Ibrahim Niftiyev.

\section{References}

1. Abdurazzakov, O., Illés, B. Cs., Jafarov, N. \& Aliyev, K. (2020). The impact of technology transfer on innovation. Polish Journal of Management Studies, 21(2), 9-23. [Google Scholar].

2. Abesadze, R. B., \& Burduli, V. Sh. (2018). Problems of Management of the National Innovation System Formation of Georgia. New Trends in Strategic and Innovation Management. Institutional Repository of Vadym Hetman Kyiv National Economic University, Section 2, 150-157. [Google Scholar]. 
3. Ahmadov, V. (2020a). The development of innovative SMEs in post-socialist countries. Proceedings of the European Union's Contention in the Reshaping Global Economy, (Ed). Udvari, B., 202-217. [CrossRef].

4. Ahmadov, V. (2020b). The Development of the Innovative SMEs in Slovakia in the Context of Macroeconomic Environment. Journal of the History of the Behavioral Sciences, 6(12), 113-120. [CrossRef].

5. Akkoyunlu, S. (2013). The Correlation between the Level of Patent Protection and International Trade. NCCR Trade Working Paper 2013/36. Bern, Switzerland: National Centres of Competence in Research. [Google Scholar].

6. Alaverdyan, D., Nagy, H., Panosyan, I. \& Kehinde, O. (2015). The impact of technology evaluation programmes on agricultural productivity in Armenia. Visegrad Journal on Bioeconomy and Sustainable Development, 4(2), 62-69. [CrossRef].

7. Alguliyev, R., Yusifov, F. \& Gurbanli, A. (2018). Methodology and Criteria for Evaluating E-Services: The Case of Azerbaijan. JeDEM-eJournal of eDemocracy and Open Government, 10(1), 106-115. [CrossRef].

8. Aliyeva, L. Z., Rzayeva, F. Z., \& Alizada, Z. I. (2021). Directions to ensure the sustainability of targeted social policy. In "Economic and Social Development: Book of Proceedings", (Eds.) Yagubov, S., Aliyev, S., \&Mikic, M., 836-846. [Google Scholar].

9. Aliyeva, N. (2020). State Of Innovative Activity In The Agriculture Of Azerbaijan. In "Economic and Social Development: Book of Proceedings", (Eds.) Ismayilov, A., Aliyev, K., \& Benazic, M., 2(4), 535-543. [Google Scholar].

10. Amirkhanyan, V. A. (2017). IT Sector as the Most Perspective High-Tech Industry in the Republic of Armenia. European Journal of Economic Studies, 6(1), 18-24. [CrossRef].

11. Ashurov, A. (2020). Some Issues Of Innovative Development Of Industrial Enterprises In Azerbaijan. In Economic and Social Development: Book of Proceedings 3, 68-76. [Google Scholar].

12. Azerbaijan - 2020: Look into the Future Development Concept. (2012). [Google Scholar].

13. Babayev, B. (2019). Building an Innovation Ecosystem as an Alternative of Oil Sector Exports in Azerbaijan (on the basis of the study of Israeli practice). Sənayenin müasir vəziyyəti və inkişaf problemləri: texnoparkların və sənaye məhəllələrinin ölkənin iqtisadi inkişafına təsiri” mövzusunda respublika elmipraktiki konfrans [Republic scientific-practical conference on "Modern state of industry and development problems: the impact of technology parks and industrial districts on the economic development of the country"], 140-143. [Google Scholar].

14. Bakhtadze, L., \& Danelia, S. (2020). The Major Determinants of Innovative Environment Formation in Georgia. Economic Alternatives, 2, 243-249 [CrossRef].

15. Baumol, W. J. (2005). Education for Innovation: Entrepreneurial Breakthroughs versus Corporate Incremental Improvements. Innovation Policy and the Economy, 5, 33-56. [CrossRef].

16. Bavec, C. (2009). On the creative climate and innovativeness at the country level. Zbornik Radova Ekonomskog Fakulteta u Rijeci : Časopis Za Ekonomsku Teoriju i Praksu, 27(1), 9-30. [Google Scholar].

17. Bhattacharya, S., \& Fernando, D. (2021). Technology Played Decisive Role in Armenia-Azerbaijan Conflict of 2020. International Journal of Research in Engineering, Science and Management, 4(9), 40-42. [Google Scholar].

18. Bigos, K. \& Wach, K. (2021). Product Innovation As The Cause Of Export Propensity In The Caucasus: Empirical Evidence For Armenia, Azerbaijan, and Georgia. Central Asia \& The Caucasus, 21(2), 90-100. [CrossRef].

19. Bokachev, I. (2020). The process of a national innovation system concept formulation: Key problems. RUDN Journal of Economics, 28(1), 98-109. [CrossRef].

20. Borrás, S., \& Edquist, C. (2015). Education, training, and skills in innovation policy. Science and Public Policy, 42(2), 215-227. [CrossRef].

21. Brodowska-Szewczuk, J. (2019). Determinants of the development of enterprises' innovativeness in the aspect of competitiveness of the economy. Entrepreneurship and Sustainability Issues, 7(2), 1279-1295. [CrossRef]. 
22. Brzozowska, A., \& Kabus, J. (2018). Determinants of enterprises' innovativeness in the light of empirical studies - case studies of Austria and Poland. Scientific Papers Of Silesian University Of Technology, Organization And Management, 116, 7-22. [Google Scholar].

23. Castellacci, F. (2011). Closing the Technology Gap? Review of Development Economics, 15(1), 180-197. [CrossRef].

24. Chechelashvili, M. (2017). State Innovative Policy of Georgia. Eurasian Union of Scientist, 7-1(40), 24-26. [Google Scholar].

25. Chepurenko, A., \& Kristalova, M. (2019). Historical and Institutional Determinants of Universities' Role in Fostering Entrepreneurship. Foresight and STI Governance, 13(4), 48-59. [Google Scholar].

26. Chi, W., \& Qian, X. (2010). The role of education in regional innovation activities: Spatial evidence from China. Journal of the Asia Pacific Economy, 15(4), 396-419. [CrossRef].

27. Chikhladze, N. \& Koguashvili, P. (2020). Innovative Approach to Rural Development in Georgia. Bulletin of the Georgian National Academy of Sciences, 14, 160-164. [Google Scholar].

28. Chiladze, G. (2017). Some Aspects of Public Policy, Strategy, and Management in the field of Intellectual Property in Georgia. GISAP Economics Jurisprudence and Management, 13, 23-25. [CrossRef].

29. Chukwuma, A. \& Koshkakaryan, M. (2018). Stakeholder Perspectives on e-Health Implementation in Armenia. World Bank Group Knowledge Brief. [Google Scholar].

30. Czerniak, J. \& Smygur, V. (2017). National Culture as a Determinant of Innovativeness. Handel Wewnętrzny, 369(4), 50-58. [Google Scholar].

31. Czyżewska, M. \& Mroczek, T. (2014). Bayesian approach to the process of identification of the determinants of innovativeness. e-Finance: Financial Internet Quarterly, 10(2), 44-56. [CrossRef].

32. Dabrowski, M. (2020). Transition to a market economy: A retrospective comparison of China with countries of the former Soviet block. Acta Oeconomica, 70(S), 15-45. [CrossRef].

33. Das, R. (2021). Cultural determinants of national innovativeness: A 56 country Bayesian analysis. Technology Analysis \& Strategic Management, 1-13. [CrossRef].

34. Despotovic, D. Z., Cvetanović, S. Ž., \& Nedić, V. M. (2014). Innovativeness and Competitiveness of the Western Balkan Countries and the Selected EU Member States. Industrija, 42(1), 27-45. [CrossRef].

35. Dieppe, A. (2021). Global Productivity: Trends, Drivers, and Policies. The World Bank. [CrossRef].

36. Divisekera, S., \& Nguyen, V. K. (2018). Determinants of innovation in tourism evidence from Australia. Tourism Management, 67, 157-167. [CrossRef].

37. Erkomaishvili, G. (2018). Economic Policy for Beginner Entrepreneurs in Georgia. International Business and Entrepreneurship, 3(V), 209-213. [Google Scholar].

38. Esmaeili, A., \& Shokoohi, Z. (2011). Assessing the effect of oil price on world food prices: Application of principal component analysis. Energy Policy, 39(2), 1022-1025. [CrossRef].

39. Fagerberg, J., \& Sapprasert, K. (2011). National Innovation Systems: The Emergence of a New Approach. Science and Public Policy, 38(9), 669-679. [CrossRef].

40. Feder, C. (2017). The effects of disruptive innovations on productivity. Technological Forecasting and Social Change, 126(C), 186-193. [CrossRef].

41. Filippetti, A., \& Peyrache, A. (2011). The Patterns of Technological Capabilities of Countries: A Dual Approach using Composite Indicators and Data Envelopment Analysis. World Development, 39(7), 11081121. [CrossRef].

42. Firlej, K. A. (2019). Expenditure on Research and Development Activities as a Determinant of the Innovativeness of the European Union's Economy. Research Papers of the Wroctaw University of Economics, 63,(7), 35-46. [CrossRef].

43. Fritsch, M., \& Schwirten, C. (1999). Enterprise-University Co-operation and the Role of Public Research Institutions in Regional Innovation Systems. Industry and Innovation, 6(1), 69-83. [CrossRef].

44. Furman, J. L., Porter, M. E., \& Stern, S. (2002). The determinants of national innovative capacity. Research Policy, 31(6), 899-933. [CrossRef].

45. Gasparyan, R. (2020). Mapping The Challenges Of Young Entrepreneurs In Armenia. The University of Tartu, School of Economics and Business Administration. [Google Scholar]. 
46. Gigauri, I. \& Damenia, N. (2019). Economic Expectations of the Belt and Road Initiative for the South Caucasus, with Emphasis on Georgia. Business and Economic Research, 9(1), 173-199. [CrossRef].

47. Gong, J., \& Li, Y. (2021). Overseas economic interest perspective in foreign policy-A case study of China. Cambridge Review of International Affairs, 0(0), 1-27. [CrossRef].

48. Gunday, G., Ulusoy, G., Kilic, K., \& Alpkan, L. (2011). Effects of innovation types on firm performance. International Journal of Production Economics, 133(2), 662-676. [CrossRef].

49. Guseynov, S., Abdullaev, R., Mehdiyev, \& T, Edelkina, A. (2021). Information \& Communication Technologies (ICT) and Economic Development of The Azerbaijan Republic, Journal of World Economy: Transformations \& Transitions, 1(1), [CrossRef].

50. Habibova, Z. \& Zeynalova, E. (2018). Human potential of communities and social entrepreneurship as a factor of sustainable innovative development in Azerbaijan. The Business and Management Review, 9(4), 5255. [Google Scholar].

51. Hasanov, N., \& Akbulaev, N. (2020). Innovative development of key sectors of the economy based on the creation of technological parks in the Republic of Azerbaijan. New Trends and Issues Proceedings on Advances in Pure and Applied Sciences, 12, 44-56. [Google Scholar].

52. Huggins, R., \& Johnston, A. (2009). The Economic and Innovation Contribution of Universities: A Regional Perspective. Environment and Planning C: Government and Policy, 27(6), 1088-1106. [CrossRef].

53. Huseynova, A., Salifova, T., \& Mazanova, O. (2019). Estimation of Innovation Activity of the Regions of the Azerbaijan Republic, Economic, and Social Development. In "Book of Proceedings; 37th International Scientific Conference on Economic and Social Development - "Socio-Economic Problems of Sustainable Development",', 41-50. [Google Scholar].

54. Inzelt, A. (2015). Re-aligning the triple helix in post-Soviet Armenia. Triple Helix, 2(1), 1-27. [CrossRef].

55. Iskandarov, K., \& Gawliczek, P. (2021). The second Karabakh war as a war of new generation. Journal of Scientific Papers "Social development and Security”, 11(2), 91-99. [CrossRef].

56. Jibuti, M. (2014). Georgia in globalized world. Bulletin of Mariupol State University Series, Mariupol State University, 34. [Google Scholar].

57. Kapanadze, M. (2021). The Potential of Action Research for Improving Science Teaching - An Experience from Georgia Need for Innovation, Action Research and Innovation in Science Education, 2(2), 1-2. [Google Scholar].

58. Kharaishvili, E. (2020). Innovations For Increasing Productivity In Agriculture And Ensuring Food Security (The Case Of Georgia). Resource document. [Google Scholar].

59. Khechoyan, T. (2018). The Interpretation of Knowledge Economy and the Problems of Its Rise and Development in Armenia. In "Book Power in Communication, Sociology, and Technology", 31-38. Trivent Publishing. [CrossRef].

60. Kinkladze, R., \& Chitaladze, K. (2018). Innovative processes in Georgia - analysis, and trends. Resource document. [Google Scholar].

61. Kitagawa, F. (2004). Universities and regional advantage: Higher education and innovation policies in English regions. European Planning Studies, 12(6), 835-852. [CrossRef].

62. Korganashvili, L., Mammadova, N., Tsotskolauri, P., \& Kochlamazashvili, L. (2017). Transformation of South Caucasus Countries During 25 Years of Independence. European Journal of Social Sciences Education and Research, 10(1), 253-262. [CrossRef].

63. Krstic, B., Stanisic, T., \& Radivojevic, V. (2016). The impact of innovativeness factors on the EU countries' competitiveness. Industrija, 44(2), 101-116. [CrossRef].

64. Kurmanov, N., Aliev, U., \& Suleimenova, S. (2019). Analysis of the Efficiency of Innovation Management in the Countries of the Eurasian Economic Union. Polish Journal of Management Studies, 19(1), 204-214. [CrossRef].

65. Kuznar, A., \& Folfas, P. (2018). How does the protection of intellectual property rights affect Hi-Tech exports from the most advanced economies? Argumenta Oeconomica, 41, 277-296. [CrossRef].

66. Lee, C. (1990). Determinants of National Innovativeness and International Market Segmentation. International Marketing Review, 7(5). [CrossRef]. 
67. Lee, S., Nam, Y., Lee, S., \& Son, H. (2016). Determinants of ICT innovations: A cross-country empirical study. Technological Forecasting and Social Change, 110, 71-77. [CrossRef].

68. Leiponen, A. (2000). Competencies, Innovation And Profitability Of Firms. Economics of Innovation and New Technology, 9(1), 1-24. [CrossRef].

69. Maglakelidze, A. (2020). Technological Innovations and Opportunities for Entrepreneurship Development in Georgia. Resource Document. [Google Scholar].

70. Majno, J., Dassel K., Labadze, M., \& Dakhundaridze, M. (2019). USAID Annual Report, USAID Governing for growth $(G 4 G)$ in Georgia: Georgia's Innovation Strategy \& Recommendations. [Google Scholar].

71. Mamedov, Z. F, Aliyev, Sh., \& Jafarova, N. (2020). Digitalization Of The Economy: Analysis Of Influence On The Banking Sphere In Azerbaijan In The Context Of World Experience, In 55th International Scientific Conference on Economic and Social Development Development, (Eds.) Ismayilov, A., Aliyev, K., \& Benazic, M., 585-591. [Google Scholar].

72. Mammadova, S (2021). Azerbaijan Health Economics In The Context Of Digitalization Of Society, In 70th International Scientific Conference on Economic and Social Development, (Eds.) Yagubov, S., Aliyev, S., \&Mikic, M., 355-359. [Google Scholar].

73. Manafov, G. N., \& Sadigov, N. A. (2021). Problems of digital entrepreneurship development in Azerbaijan, Economic and Social Development. 70th International Scientific Conference on Economic and Social Development Development, (Eds.) Yagubov, S., Aliyev, S., \&Mikic, M., 660-665. [Google Scholar].

74. Manucharyan, M. G. (2021). The Development of Innovative Economy in Armenia: Trends and Problems. Большая Евразия: Развитие, безопасность, сотрудничество, 4(1), 480-482. [Google Scholar].

75. Martínez-Román, J. A., \& Romero, I. (2017). Determinants of innovativeness in SMEs: Disentangling core innovation and technology adoption capabilities. Review of Managerial Science, 11(3), 543-569. [CrossRef].

76. Mercan, B., \& Göktaş, D. (2011). Components of Innovation Ecosystems: A Cross-Country Study. International Research Journal of Finance and Economics, 76, 102-112. [Google Scholar].

77. Mir-Babayev, R., Gulaliyev, M., Shikhaliyeva, S., Azizova, R., \& Ok, N. (2017). The impact of Cultural Diversity on Innovation Performance: Evidence from construction Industry of Azerbaijan, Economics and Sociology, 10(1), 78-93. [CrossRef].

78. Mkrtchyan, A. (2010), Armenia: The Innovation Performance, Helsinki. [Google Scholar].

79. Morck, R., \& Yeung, B. (2001). The economic determinants of innovation. Industry Canada Research Publications Program. Occasional Paper 25. [Google Scholar].

80. Ng, E., \& Tan, B.(2018). Achieving state-of-the-art ICT connectivity in developing countries: The Azerbaijan model of Technology Leapfrogging. Electronic Journal of Information Systems in Developing Countries. 84(3), 1-14. [CrossRef].

81. Noniashvili, M. (2020). The Tech Platform as Innovative Teaching Model at High Schools in Georgia. Journal of Eastern European and Central Asian Research (JEECAR), 7(1), 95-103. [CrossRef].

82. OECD - Organisation for Economic Co-operation and Development. (2011). Fostering innovation for Green growth, OECD Green growth studies. [Google Scholar].

83. OECD - Organisation for Economic Co-operation and Development \& Statistical Office of the European Communities (2005). Measurement of Scientific and Technological Activities: Manual on the Measurement of Human Resources Devoted to S\&T - Canberra Manual. OECD. [CrossRef].

84. Parlinska, A. \& Avetisyan, L. (2016). The role of leasing in financing of innovation in Europe and Armenia. Zeszyty Naukowe Szkoły Gtównej Gospodarstwa Wiejskiego w Warszawie. Polityki Europejskie, Finanse $i$ Marketing, 16(65). [Google Scholar].

85. Qin, Y. J., Mkhitaryan, D., \& Bhuiyan, M. A. (2017). University-Industry Collaboration in Armenia, DEStech Transactions on Engineering and Technology Research. International Conference on Applied Mechanics and Mechanical Automation. [Google Scholar].

86. Radjabov, B. (2019). A Critical Analysis of UNDP-Supported "Social Innovation" Projects in Local Governance in Armenia, Ukraine and Uzbekistan. Journal of International and Advanced Japanese Studies 11, 99-120. [Google Scholar]. 
SocioEconomic Challenges, Volume 5, Issue 4, 2021 ISSN (print) - 2520-6621, ISSN (online) - 2520-6214

87. Rahimova, V. (2020). Organizing Production Innovation in Azerbaijan and Researching Modern Development Trends, In 55th International Scientific Conference on Economic and Social Development, (Eds.) Ismayilov, A., Aliyev, K., \& Benazic, M., 158-166. [Google Scholar].

88. Rahmanov, F. P, E. Suleymanov, \& Y. Özdemir (2018). Improving the Institutional Environment of the Innovation Economy in Azerbaijan, Online Academic Journal of Information Technology (9), 35. [CrossRef].

89. Roberts, J. M., Cohen, A., \& Blaisdell, J. C. (2013). Eurasian Union: Undermining Economic Freedom and Prosperity in the South Caucasus. Special Report from The Center For International Trade and Economics (CITE). 148. [Google Scholar].

90. Sadigov, T. (2017). Adoption of agricultural innovations in Azerbaijan: no prospects for modernization. Caucasus Survey, 6(1), 42-61. [CrossRef].

91. Sadik-Zada, E. R. (2021). Natural resources, technological progress, and economic modernization. Review of Development Economics, 25(1), 381-404. [CrossRef].

92. Sadik-Zada, E. R., Loewenstein, W., \& Hasanli, Y. (2019). Commodity Revenues, Agricultural Sector and the Magnitude of Deindustrialization: A Novel Multisector Perspective. Economies, 7(4), 113. [CrossRef].

93. Sadik-Zada, E. R., Loewenstein, W., \& Hasanli, Y. (2021). Production linkages and dynamic fiscal employment effects of the extractive industries: Input-output and nonlinear ARDL analyses of Azerbaijani economy. Mineral Economics, 34(1), 3-18. [CrossRef].

94. Schaeffer, P. R., Fischer, B., \& Queiroz, S. (2018). Beyond Education: The Role of Research Universities in Innovation Ecosystems. Фopcaüm, 12(2), 50-61. [Google Scholar].

95. Schumpeter, J. A. 1934 (2008). The theory of economic development: An inquiry into profits, capital, credit, interest, and the business cycle. Journal of Comparative Research in Anthropology and Sociology. 3(2), 137148. [Google Scholar].

96. Shaburishvili, Sh., \& Javakhishvili, I. (2017). Global Innovation Trends and Georgia. European Journal of Economics and Business Studies, 3(2), 94-99 [CrossRef].

97. Shehadi, S. (2021). Why Baku is backing away from oil dependence. Investment Monitor. Available at: [Link]. Accessed: 01 October 2021.

98. Strahl, D., \& Sobczak, R. (2017). Conceptual roots for innovation and innovativeness of the economy in Poland. GeoScape, 11(1). 41-51. [CrossRef].

99. Suleymanli, O. Z. (2020). Global Innovation Index For Performance Ranking: The Position of Azerbaijan, Ípək Yolu, (1), 125-133. [Google Scholar].

100. Sultanova, R. P., \& Khankishiyeva, E. (2021). Innovation as a necessary factor in the development of the gold mining industry in Azerbaijan, Innovation Policy and Innovation Management. Innovations, 9(3), 2932. [Google Scholar].

101. Takalandze, L. (2017). Some Issue of Strategic Development of Georgia. In II International scientificpractical forum, (Eds.) Dei, M. \& Rudenko, O., 154-156. [Google Scholar].

102. Tamar, G. \& Lamara, K. (2020) Innovative Financial Instruments to Ensure The Advancement of SME in Georgia. European Science Review, 3-4, 73-79. [CrossRef].

103. Tatevik, P., (2017). State of the National Innovation System of Armenia. 49-67. [CrossRef].

104. Toner, P. (2010). Innovation and Vocational Education. The Economic and Labour Relations Review, 21(2), 75-98. [CrossRef].

105. UNECE - United Nations Economic Commission for Europe. (2021). Sub-regional innovation policy outlook 2020: Eastern Europe and the South Caucasus: Armenia, Azerbaijan, Belarus, Georgia, Republic of Moldova, Ukraine. United Nations. Available at: [Link]. Accessed: 02 October 2021.

106. UNECE - United Nations Economic Commission for Europe. (2020). Innovation for Sustainable Development - Review of Georgia. [Google Scholar].

107. van der Panne, G., \& van Beers, C. (2006). On the Marshall-Jacobs controversy: It takes two to tango. Industrial and Corporate Change, 15(5), 877-890. [CrossRef].

108. Violante, G. L. (2016). Skill-Biased Technical Change. In The New Palgrave Dictionary of Economics, 1-6, Palgrave Macmillan UK. [CrossRef]. 
109. World Bank Group. (2020), Realizing Armenia's High-Tech Potential. Available at: [Link]. Accessed: 01 October 2021.

110. Choi, Y.C. (2021). Korea's ODA Policy Direction for Azerbaijan: Strengthening Azerbaijan's Innovation Policy Capabilities, Turkish Journal of Computer and Mathematics Education 12(13), 1590-1606. [Google Scholar].

111. Youtie, J., Shapira, Ph., \& Roper, S. (2018). Exploring Links Between Innovation and Profitability in Georgia Manufacturers. Economic Development Quarterly, 32(7), 1-17. [CrossRef].

112. Zeynalov, A. (2021). Organizational Citizenship Behaviour in Azerbaijan: The Case of ASAN SERVICE. Bulletin of the Taras Shevchenko National University of Kyiv. Public Administration, 2(14), 10-13. Available at: [Link]. Accessed: 04 October 2021. 